NBER WORKING PAPER SERIES

\title{
DIVIDEND POLICY, AGENCY COSTS, AND EARNED EQUITY
}

\author{
Harry DeAngelo \\ Linda DeAngleo \\ René M. Stulz \\ Working Paper 10599 \\ http://www.nber.org/papers/w10599
}

\author{
NATIONAL BUREAU OF ECONOMIC RESEARCH \\ 1050 Massachusetts Avenue \\ Cambridge, MA 02138
}

June 2004

This research was supported by the Charles E. Cook/Community Bank and Kenneth King Stonier Chairs at USC and the Everett D. Reese Chair at OSU. René Stulz is grateful for the hospitality of the Kellogg Graduate School of Management at Northwestern University and the George G. Stigler Center for the Study of the Economy and State at the University of Chicago. We thank Qi Qin, Xuhu Wan, and Sam Zhang for research assistance, and especially April $\mathrm{Xu}$ for her diligent and outstanding work on this project. We also thank seminar participants at the University of Chicago for helpful comments. The views expressed herein are those of the author(s) and not necessarily those of the National Bureau of Economic Research.

C2004 by Harry DeAngelo, Linda DeAngelo, and René M. Stulz. All rights reserved. Short sections of text, not to exceed two paragraphs, may be quoted without explicit permission provided that full credit, including (C) notice, is given to the source. 
Dividend Policy, Agency Costs, and Earned Equity

Harry DeAngelo, Linda DeAngelo, and René M. Stulz

NBER Working Paper No. 10599

June 2004

JEL No. G35, G32, M41, K22, H3

\section{ABSTRACT}

Why do firms pay dividends? If they didn't their asset and capital structures would eventually become untenable as the earnings of successful firms outstrip their investment opportunities. Had they not paid dividends, the 25 largest long-standing 2002 dividend payers would have cash holdings of $\$ 1.8$ trillion (51\% of total assets), up from $\$ 160$ billion ( $6 \%$ of assets), and $\$ 1.2$ trillion in excess of their collective $\$ 600$ billion in long-term debt. Their dividend payments prevented significant agency problems since the retention of earnings would have given managers command over an additional \$1.6 trillion without access to better investment opportunities and with no additional monitoring. This logic suggests that firms with relatively high amounts of earned equity (retained earnings) are especially likely to pay dividends. Consistent with this view, the fraction of publicly traded industrial firms that pays dividends is high when the ratio of earned equity to total equity (total assets) is high, and falls with declines in this ratio, becoming near zero when a firm has little or no earned equity. We observe a highly significant relation between the decision to pay dividends and the ratio of earned equity to total equity or total assets,controlling for firm size, profitability, growth, leverage, cash balances, and dividend history. In our regressions, earned equity has an economically more important impact than does profitability or growth. Our evidence is consistent with the hypothesis that firms pay dividends to mitigate agency problems.

$\begin{array}{lll}\text { Harry DeAngelo } & \text { Linda DeAngelo } & \text { René M. Stulz } \\ \text { Marshall School of Business } & \text { Marshall School of Business } & \text { Fisher College of Business } \\ \text { University of Southern California University of Southern CaliforniaOhio State University } \\ \text { hdeangelo@marshall.usc.edu } & \text { ldeangelo@marshall.usc.edu } & \text { 806A Fisher Hall } \\ & & \text { 2100 Neil Avenue } \\ & & \text { Columbus, OH 43210-1144 } \\ & \text { and NBER } \\ & \text { stulz@cob.osu.edu }\end{array}$




\section{Dividend Policy, Agency Costs, and Earned Equity}

\section{Introduction}

Firms pay dividends because if they didn’t their asset and capital structures would eventually become untenable as the earnings of successful firms outstrip their investment opportunities. To date no study has explored the impact on the balance sheets of long-time dividend payers of retaining the earnings they previously paid out. We do so and conservatively estimate that, had the 25 largest long-standing dividend-paying industrial firms in 2002 not paid dividends, they would have cash holdings of \$1.8 trillion (51\% of total assets), up from $\$ 160$ billion (6\% of assets), and $\$ 1.2$ trillion in excess of their collective $\$ 600$ billion in long term debt. Absent dividends, these firms would have huge cash balances and little or no leverage, vastly increasing managers' opportunities to adopt policies that benefit themselves at stockholders' expense. When managers' objectives differ from shareholders', using incentive contracts to control managerial opportunism is less effective than simply paying out excess cash (Jensen (1986)). And so, as stockholders observe earned equity (retained earnings) accumulate on the balance sheet, they will increasingly pressure managers to pay dividends to avoid the high cash/low debt financial structures and associated agency problems that would otherwise eventually result.

Managers acquire control over corporate resources either from outside contributions of debt or equity capital, or from earnings retentions. From an agency perspective, one advantage of contributed capital is that it comes with additional monitoring, since rational suppliers of outside capital will not be forthcoming with funds at attractive prices if they believe that managers' policies merit low valuations (Jensen and Meckling (1976), Easterbrook (1984)). Earned equity is not subject to the same ongoing, stringent discipline. Accordingly, potential agency problems are higher when a firm's capital is largely earned, since the more a firm is "self-financed" through retained earnings, the less it is subject to the ongoing discipline of capital markets. Looking forward, firms with a greater demonstrated ability to selffinance most likely are also firms with greater ability to fund projects internally that reduce stockholder wealth. Such potential wastage is limited by ongoing distributions that reduce the scale of resources under managerial control -- i.e., a regular stream of dividends reduces the threat of agency problems that 
becomes increasingly serious as earned equity looms ever larger in the firm’s capital structure.

In this paper, we test the hypothesis that the probability that a firm pays dividends increases with higher levels of earned equity (as a fraction of total common equity and of total assets). For the 25 longstanding dividend payers discussed above, the median ratio of earned to total equity is $97 \%$, suggesting that this measure does in fact identify historically profitable firms with potentially large agency problems. Our evidence is uniformly and strongly consistent with the prediction that the probability of paying dividends increases with the amount of earned equity in the capital structure. For publicly traded industrials over 1973-2002, the proportion of firms that pays dividends is high when the ratio of earned to total common equity is high, and falls with declines in this ratio, reaching near-zero levels when firms have negligible retained earnings. Similarly, the proportion that pays dividends is high when earned equity is a large fraction of total assets and decreases (eventually approaching zero) as the ratio of earned equity to total assets declines. We find no such monotonic relation between the proportion of firms that pays dividends and total common equity, indicating that earned equity per se is a key determinant of the decision to pay dividends.

Using a broad variety of multivariate logit specifications, we consistently observe a positive and highly significant relation between the probability that a firm pays dividends and the relative importance of earned equity in its capital structure, controlling for firm size, current and lagged profitability, growth, leverage, cash balances, and dividend history. The coefficients on our measures of the relative amount of earned equity are of the predicted sign and statistically significant in every logit specification we run, with Fama-MacBeth t-statistics in the double digits in almost every regression (and in no case less than 5.7). Our logits also consistently reveal statistically significant relations between the probability a firm pays dividends and its size, profitability, and growth (as in Fama and French (2001)), indicating that the impact of earned equity on the decision to pay dividends that we document here is an empirically distinct phenomenon from other factors that have previously been shown to affect the dividend decision.

The relation between the probability of paying dividends and earned equity is not only statistically significant (as indicated by uniformly high t-statistics in our logit regressions), but it is also 
economically significant. We examine how the estimated probability of paying dividends varies with the ratio of earned to total equity (RE/TE), holding constant firm size and the other determinants of the dividend decision. The difference between low and high values of RE/TE translates to a substantial difference in the probability of paying dividends for all but the highest size deciles of NYSE firms, and smaller but still nontrivial differences for the largest firms. For firms the size of the median NYSE firm, the probability of paying dividends increases from about $50 \%$ to more than $80 \%$, moving from RE/TE $=$ 0.10 to $\mathrm{RE} / \mathrm{TE}=0.90$. For firms at the $90^{\text {th }}$ size percentile, the probability increase, from $80 \%$ to $95 \%$, is smaller because the unconditional probability of paying dividends is high for these large firms. The estimated probability impact of differences in firm size is also substantial, but differences in current profitability and growth have an economically modest impact on the probability of paying dividends.

Section 2 documents how a decision to retain earnings rather than pay dividends would have affected the asset structures of the 25 dividend payers in 2002 that paid the largest total dividends over 1950-2002, and discusses why these firms likely distributed so much cash through dividends rather than through stock repurchases. Section 3 outlines the sampling procedure for our main statistical tests and presents descriptive statistics for dividend payers and nonpayers. Section 4 presents univariate analyses that relate the proportion of firms that pays dividends to the amount of earned equity in the capital structure. Sections 5 and 6 report our central findings, with the former section describing our basic logit regressions that assess the relation between the probability that a firm pays dividends and its earned equity, and the latter section reporting the results of sensitivity checks on our basic results. Section 7 presents evidence on the economic materiality of our results. Section 8 summarizes our findings.

\section{Asset and capital structure consequences of the decision to pay dividends}

Table 1 reports total inflation-adjusted dividends, as well as 2002 cash balances and long-term debt for the 25 industrial firms that paid dividends in that year and that distributed the largest total real dividends over 1950-2002. Total real dividends in column (1) is our estimate of the incremental resources these firms would have in 2002 had they paid no dividends over 1950-2002 and not altered any 
other aspect of investment and financial policy. In constructing these estimates, we conservatively assume that firms would have earned a zero after-tax real return on the foregone dividends. Columns (2) and (3) report the actual year 2002 values of cash plus marketable securities and long-term debt in billions of year 2002 dollars, while column (4) contains the actual ratio of cash plus marketable securities to total assets (Cash/TA). Columns (5) and (6) describe hypothetical Cash/TA values for the 25 firms under two scenarios: first, that they use the proceeds from foregone dividends to increase cash balances, and second, that they apply the proceeds to reduce long-term debt to the extent possible, with any remainder increasing cash balances. Comparison of actual and "as if" values of Cash/TA reveals the de facto impact of a given firm's chosen dividend policy on its 2002 asset structure.

Over 1950-2002 the 25 firms in table 1 collectively paid real dividends of \$1.6 trillion, or about \$1 trillion more than their 2002 aggregate long-term debt of \$639 billion. The \$1.6 trillion figure is conservative because it ignores two important sources of additional cash from foregone dividends. ${ }^{1}$ First, most of the 25 firms paid dividends for many years prior to 1950, e.g., General Motors paid an additional $\$ 48.5$ billion in real dividends over 1917-1949. Second, our estimate excludes the pre-acquisition dividends paid by target firms acquired by parents in the table, e.g., the dividends reported for Exxon Mobil exclude \$56.5 billion in real dividends paid over 1950-1998 by Mobil prior to its 1999 merger with Exxon. Under our conservative assumptions, the 25 firms’ cash balances would increase from \$157 billion to \$1.8 trillion had they foregone dividends over 1950-2002. Alternatively, they could have fully paid off their 2002 long-term debt and had an extra \$1 trillion in cash on hand. Had the median firm chosen to increase cash balances with no debt pay down, cash would increase from $6 \%$ to $51 \%$ of total assets. Had it first paid down all long-term debt outstanding, cash would instead be $48 \%$ of total assets.

These findings provide a compelling empirical explanation for why firms pay dividends. Simply put, for historically profitable firms, the alternative to paying dividends is to ultimately create an asset and capital structure that is radically out of sync with any reasonable estimate of attractive investment

\footnotetext{
${ }^{1}$ Our assumption that foregone dividends earn a zero real return is also conservative. A positive real return of $1 \%$ would raise our estimate of incremental cash balances (from foregoing dividends) from $\$ 1.6$ trillion to $\$ 2$ trillion.
} 
opportunities the firm might currently have or might reasonably expect to encounter in future periods. Under the hypothetical zero dividend policy, the 25 firms in table 1 collectively have the wherewithal to immediately invest an incremental \$1 trillion with no long-term debt, and to invest more than $\$ 1$ trillion after taking into account their unutilized debt capacity. Managers who work in the best interests of stockholders have incentives to avoid unprofitable projects and to distribute any excess cash, so that dividend policy is one vehicle through which they can reduce the agency costs of free cash flow (Jensen (1986)). In this view, paying dividends sharply reduced agency costs for these 25 firms. Stock repurchases are an alternative way to reduce agency costs, and the 25 firms spent at least another \$209 billion on repurchases (a conservative estimate not counted in the \$1.6 trillion from foregone dividends).

Feldstein and Green (1983) and others argue that the tax authorities would not allow unfettered tax avoidance through full displacement of dividends by stock repurchases. Had the 25 firms chosen to distribute the entire \$1.6 trillion in foregone dividends as stock repurchases, the Internal Revenue Service would surely have taken notice since, assuming a $10 \%$ difference in the tax rates on dividends and repurchases, this wholesale substitution would generate a real tax revenue loss of roughly $\$ 160$ billion. Such a blatant attempt at tax avoidance by 25 of the largest U.S. corporations would almost surely have triggered a public outcry and a crackdown by the IRS that would have reduced or eliminated the nominal tax advantage of repurchases over dividends. ${ }^{2}$ Viewed in this light, it is easy to see why firms pay large dividends even though a comparison of the statutory tax rates on dividends and repurchases suggests that repurchases should have largely replaced dividends. Moreover, a simple comparison of tax rates ignores the fact that regular dividends represent an implicit commitment to continue distributions, thereby providing a stronger check on excess retention, hence a greater reduction in agency costs for firms with an ongoing ability to generate substantial free cash flow.

\footnotetext{
${ }^{2}$ To put the $\$ 160$ billion estimate in perspective, consider the headline from the following recent page one article in the Wall Street Journal: "KPMG Shelter Shaves \$1.7 Billion Off Taxes of 29 Large Companies" (June 16, 2004). The same argument also applies to the payout versus retention decision. Had the 25 firms simply retained the cash and foregone both dividends and repurchases, the IRS would also surely have taken notice of the $\$ 1.8$ trillion incremental cash build-up by a handful of large, highly visible corporations, and would likely have acted to enforce the surtax on excessive retention.
} 
Our empirical work focuses on retained earnings, under the assumption that large amounts of earned relative to contributed capital identifies successful firms that face potential agency costs should they fail to distribute cash to stockholders. We draw a sharp distinction between earned and contributed equity capital since, as Jensen and Meckling (1976) and Easterbrook (1984) argue, rational outside investors will constrain agency problems by offering low prices for new shares when the potential for waste is large. Internally generated equity is not subject to the same degree of stockholder oversight, and thus more plausibly allows managers to waste resources. It does not follow that firms should pay dividends in every period, since flotation costs, personal taxes, and Myers and Majluf (1984) style asymmetric information problems all imply that dividends financed by stock issuances impose unnecessary costs on stockholders. The latter fact suggests that firms will avoid paying dividends when their capital structures contain relatively little earned equity, i.e., when their attractive investment opportunities cannot be financed internally. ${ }^{3}$ Nevertheless, agency costs will eventually become important as earned equity becomes an increasingly large element of a firm’s capital structure.

\section{Sampling procedure and descriptive statistics}

Our sampling procedure parallels those used by Fama and French (2001) and DeAngelo, DeAngelo, and Skinner (2004). Specifically, we restrict analysis to nonfinancial and nonutility (hereafter, industrial firms) on CRSP and Compustat, defined as firms with SIC codes outside the intervals 49004949 and 6000-6999. We consider only NYSE, NASDAQ, and AMEX firms that have securities with CRSP share codes 10 or 11 and that are incorporated in the U.S. according to Compustat. We focus on 1973-2002, since CRSP expands to include NASDAQ firms in 1972. To be included in our sample for a given year, a firm must have nonmissing values for dividends and earnings before extraordinary items on Compustat in that year. We also impose other Compustat data availability conditions when conducting some of our logit tests and related analyses (details are provided below where appropriate).

\footnotetext{
${ }^{3}$ Firms with relatively little earned equity may also avoid paying dividends because dividends increase leverage, and high equity capital structures have benefits when uncertainty about investment prospects is especially great (Stulz (1990)), as seems plausible for such firms.
} 
We measure a firm's earned equity (retained earnings) relative to both total common equity capital, RE/TE, and to total assets, RE/TA. The RE/TE formulation assumes that the key determinant of the decision to pay dividends is the proportion of (common) equity from internal sources, while the RE/TA formulation assumes that the key determinant is the amount of total assets funded by earned rather than contributed capital of all types. Since neither measure fully captures the possible impact of leverage on the dividend decision, many of our logits also include TE/TA, the ratio of total common equity to total assets. We obtain highly significant results for both the RE/TE and RE/TA measures whether we include or exclude our leverage control, TE/TA. In the tables presented below, we emphasize the RE/TE results on the intuitive grounds that this variable excludes any impact of debt per se (unlike RE/TA which includes debt in the TA denominator) and it seems desirable a priori to avoid confounding earned equity and leverage effects. Given that our results are robust to the choice of earned equity measure (our RE/TA results are actually stronger, as detailed in section 6.4), the decision to emphasize the RE/TE results makes no difference for the inferences we draw in this paper.

For the 25 firms in table 1, the median RE/TE is $97 \%$, suggesting that this measure reasonably identifies historically profitable firms that face or soon will face agency problems. Intuitively, it would seem that the higher its level of cash balances, the greater the likelihood a firm pays dividends. For the table 1 firms, all of which have paid and continue to pay substantial dividends, the ratio of cash to total assets is a modest $6 \%$ (about the same as for the median firm in Opler, Pinkowitz, Stulz, and Williamson (1999, table 1)), an observation that runs counter to this intuition. Although we use cash as a control in some of our logit regressions, we believe it is a poor indicator of whether a firm is likely to pay dividends. Specifically, a firm's high cash balances (and low RE/TE) may primarily reflect a recent equity offering whose proceeds are earmarked for new investment. The high cash balance erroneously indicates a high probability of paying dividends, whereas the low RE/TE accurately identifies a firm at the equity infusion, not at the cash distribution stage, and one that is therefore unlikely to pay dividends.

Our central prediction is that the probability that a firm pays dividends increases with its level of earned capital, as proxied by RE/TE (or RE/TA). We deliberately couch this prediction in probability 
terms rather than as an exact prediction because the decision to pay dividends also depends on a firm's investment opportunities, which we can measure only imperfectly. Although our logits include all of the variables typically used to control for investment prospects (market-to-book ratio, sales growth rate, asset growth rate), these variables are rough measures of the scale of profitable investment opportunities for a given firm. Accordingly, our statistical tests implicitly assume that RE/TE (RE/TA) is not positively correlated with investment opportunities that our market-to-book and growth controls fail to capture, i.e., that a high RE/TE (RE/TA) does not identify firms with investment opportunities greater than expected by the market or than implied by recent growth rates.

The GAAP treatment of stock dividends and repurchases introduces measurement error into RE/TE and RE/TA. Stock dividends transfer amounts from RE to contributed equity, thus understating RE. Repurchased shares held as treasury stock reduce TE and TA, but not RE, and therefore overstate RE/TE and RE/TA. This effect can be substantial when many shares are repurchased and/or when shares are repurchased at prices materially higher than the initial issue price. In extreme cases, stock repurchases can result in negative TE and so, when we calculate RE/TE we exclude observations with non-positive denominators (in the median year over 1973-2002, 4.6\% of sample observations have negative TE). Given the large increase in the dollar volume of repurchases since the mid-1980s, our main concern is for measurement error in the later years of our sample period, since the early years have relatively few repurchases. As detailed in section 6.5, GAAP-induced measurement error does not affect any of our inferences, since earned equity is a significant determinant of the decision to pay dividends both before and during the repurchase boom (although, as expected, the t-statistics are higher before the boom).

Table 2 presents summary statistics for the various explanatory variables that we use throughout the paper. The table groups variables into those that measure (i) the relative amounts of earned equity in the capital structure (RE/TE and RE/TA), (ii) the total use of common equity financing (TE/TA), which can also be interpreted as the complement of total leverage when preferred stock is viewed as a fixed charge obligation, (iii) profitability, as measured by the current period return on assets (ROA), (iv) growth, as measured by the sales growth rate (SGR), asset growth rate (AGR), and market-to-book ratio 
(M/B)), (v) size, as measured by the asset (NYA) and equity value (NYE) percentiles for firms listed on the NYSE, and (vi) holdings of cash plus marketable securities as a fraction of total assets (Cash/TA). For each variable, we first calculate the median value in each given year for firms that paid and did not pay dividends in that year, and then calculate the median over 1973-2002 of the time series of annual medians to obtain the numbers reported in the table.

Table 2 shows that dividend payers typically have considerably greater relative amounts of earned equity than do nonpayers. For example, $75 \%$ of the total common equity is earned rather than contributed for the median dividend payer, whereas less than $4 \%$ is earned for the median nonpayer. When earned equity is measured as a percent of total assets, it is $34 \%$ for the median dividend payer, versus a negative $1.5 \%$ of assets for the median nonpayer. These differences in the relative amounts of earned equity are not driven by capital structure differences across payers and nonpayers, insofar as the overall reliance on total equity financing differs little across the two groups, with a median TE/TA ratio of $48 \%$ for dividend payers and $47 \%$ for nonpayers.

Fama and French (2001) document that the probability that a firm pays dividends is positively related to profitability and size and negatively related to growth. The intuition is that higher profitability and greater size imply a greater capacity to distribute cash, whereas greater growth indicates superior investment opportunities, thus a stronger incentive to retain cash. Table 2 shows that, consistent with Fama and French (2001), dividend payers are more profitable and larger than nonpayers (see ROA, NYA, and NYE in rows 4, 8, and 9). Also as expected, nonpayers typically exhibit greater sales growth (see SGR in row 5) and higher market-to-book ratios (see M/B in row 7), although differences in median M/B ratios are modest. Contrary to expectations, the median asset growth rate of payers is a bit higher than that of nonpayers (see AGR in row 6). AGR automatically increases with earnings, and higher earnings increase the probability of paying dividends for reasons unrelated to growth prospects, making AGR a less than ideal growth measure. This shortcoming is not important here since we obtain substantively identical logit results using AGR, SGR, or M/B. Finally, table 2 indicates that dividend payers have lower cash ratios than nonpayers (see Cash/TA in row 10, and our earlier discussion why high cash 
balances do not necessarily indicate a high likelihood of paying dividends).

\section{Earned equity and the proportion of firms that pays dividends: Univariate analysis}

Table 3 reveals a strong monotonic and positive relation between the proportion of firms that pays dividends and earned equity, as measured both by RE/TE and RE/TA. For RE/TE, RE/TA, and TE/TA, in each year from 1973-2002, we calculate the ratio of dividend payers to total firms that fall into a specified interval ranging from zero or less to $90 \%$ or more. The numbers reported in panels $\mathrm{A}$, B, and C of the table are the medians of these annual proportions over 1973-2002 (and the median number of firms in each category over the 30 year period) for RE/TE, RE/TA, and TE/TA, respectively. Panel A shows that only $3.6 \%$ of firms with negative RE/TE pay dividends. The percent of payers rises to $13.7 \%$ for RE/TE between 0.00 and 0.10 , and then increases steadily for every subsequent 0.10 increase in RE/TE, reaching $81.0 \%$ when RE/TE is 0.90 or greater. Panel B reports a similarly strong monotonic relation for RE/TA. The one exception is when RE/TA is 0.90 or greater, which is easily explained by the small sample size for this category (12 firms for the median year over 1973-2002, per table 3).

Although panels A and B describe a strong monotonic relation between the fraction of firms that pays dividends and our two measures of earned equity, RE/TE and RE/TA, we find no such crosssectional relation for total common equity, TE/TA. In fact, panel C reveals a low proportion of dividend payers among the firms with both high and low TE/TA, and a substantially higher proportion among firms with intermediate TE/TA. It is easy to see why firms with low TE/TA pay dividends infrequently, since a low TE/TA ratio (high financial leverage) is often a sign of financial trouble. At the high end of the TE/TA distribution, there are two types of firms, those for which the high total equity comes primarily from earned equity and those for which it comes primarily from contributed equity. The former firms are good candidates to pay dividends, while the latter are poor candidates. During our sample period, firms with relatively high contributed equity dominate the set of high TE/TA firms and so, in marked contrast to our findings for RE/TE and RE/TA, high TE/TA firms exhibit a low proportion of dividend payers. 


\section{Earned equity and the probability of paying dividends: Multivariate analysis}

We use Fama and French’s (2001, section 3.5) Fama-MacBeth-based statistical methodology to test the hypothesis that the probability a firm pays dividends depends systematically on the amount of earned equity in its capital structure. We first specify a multivariate logit model in which the payment/nonpayment of dividends in a given year is the dependent variable, and in which the explanatory variables are RE/TE (or RE/TA, results reported in section 6.4) and other potential determinants of the dividend decision. For each model, we run separate logit regressions for each of the 30 sample years (1973-2002) to obtain a time-series of fitted coefficients, which are inputs to t-statistics that gauge the statistical significance of our explanatory variables. We gauge their economic significance in section 7.

We employ a broad variety of model specifications and alternative control variables, since extant theories offer only rough guidelines about the key determinants of the decision to pay dividends, and of the best ways to capture those determinants empirically. In specifying the control variables for our tests, we use Fama and French's measures of profitability, growth, and size (ROA, AGR or M/B, and NYE, as defined earlier). Since market-to-book ratios vary over time with the level of the stock market, we follow Fama and French (2004) and standardize each M/B input to the logit regressions for a given year by the overall $\mathrm{M} / \mathrm{B}$ ratio for all sample firms in that year. As sensitivity checks, we also estimate logit models with an asset-based measure of firm size (NYA) and with the sales growth rate (SGR) in place of AGR.

Table 4 contains test results for four basic models (denoted A-D), each of which is run with six different sets of variables that control for growth and size (denoted by the suffix 1-6 in the model ID column). The suffix 1 indicates that we measure size by NYE and growth by AGR, while suffixes 2-6 respectively indicate the following size and growth control variable combinations: NYE and SGR, NYE and M/B, NYA and AGR, NYA and SGR, and NYA and M/B. Our findings of a systematic link between $\mathrm{RE} / \mathrm{TE}$ and the probability that a firm pays dividends are robust across these alternative control variable combinations. The same is true of all logit inferences drawn from data reported in subsequent tables. For brevity, we do not report the details for all six combinations in subsequent tables, but simply report test results using annual sales growth (SGR) and the equity value-based size measure (NYE). The similarity 
of results across specifications that is evident in table 4 characterizes all tests reported in subsequent tables with SGR and NYE as controls.

In table 4, models A1-A6 relate the decision to pay dividends to firm profitability, growth, and size, which are the main determinants of this decision as posited by Fama and French (2001, table 5), while models B1-B6 add total equity, TE/TA, as an explanatory variable. The time-series average of the fitted logit coefficients appears on the left side of the table, with t-statistics on the right. The results for models A1-A6 and B1-B6 are fully consistent with the findings of Fama and French, with all specifications showing that the probability that a firm pays dividends is significantly and positively related to profitability and size, and negatively to growth. The probability of paying dividends is positively related to the total use of equity financing, but the relation is insignificant at conventional levels in two of the six specifications (B1 and B2). The weak evidence of a systematic TE/TA effect indicates that the strong earned equity effect documented below is not attributable to the intensity with which the firm employs equity capital per se, but rather to its use of earned equity.

Specifications C1-C6 in table 4 add RE/TE, the ratio of earned to total equity capital, to the basic Fama and French model, while specifications D1-D6 add RE/TE to the TE/TA-inclusive version of their model. In all these specifications, we find a highly significant positive relation (with Fama-MacBeth tstatistics in the double digits) between RE/TE and the probability of paying dividends. The relations with profitability, growth, and size remain significant and, although the coefficients on current profitability decrease, the t-statistics largely remain in the double-digits. [We discuss the relation between RE/TE and profitability in section 6.3 below.] The t-statistics on total equity, TE/TA, remain mixed, with some models showing a significantly positive relation with the probability of paying dividends, and others showing an insignificantly negative relation. Although logit $\mathrm{R}^{2} \mathrm{~s}$ are known to be imperfect measures of overall explanatory power, the $\mathrm{R}^{2} \mathrm{~s}$ are all in the $35 \%$ region for models that include RE/TE, versus the 26-28\% range for specifications that exclude this measure. In sum, the table 4 logit regressions consistently show a strong relation between the probability that a firm pays dividends and its earned equity, controlling for variables that Fama and French show affect this decision. 


\section{Earned equity and the probability of paying dividends: Sensitivity analysis}

The sensitivity checks we next present collectively indicate that table’s 4 finding of a significant relation between the probability of paying dividends and the relative amount of earned equity is robust to alternative model specifications and measures of explanatory variables. Sections 6.1, 6.2, and 6.3 respectively discuss the impact of controlling for cash balances, prior dividend history, and lagged profitability. Section 6.4 establishes that our logit results are robust to the use of RE/TA in place of RE/TE to capture the relative amount of earned equity in firms' capital structures. Section 6.5 presents evidence that measurement error introduced by the GAAP treatment of stock repurchases does not alter our inferences, as our logit findings continue to hold in time periods of relatively high and low amounts of repurchase activity. Section 6.6 documents that the earned equity of the typical dividend initiator (and omitter) falls between that of the typical payer and nonpayer, and presents logit results which indicate that the level of earned equity is a significant determinant of dividend initiation and omission decisions.

\subsection{Controlling for cash balances}

Cash balances and earned equity are conceptually distinct economic variables. If we ignore accounting accruals and there are no non-operating income items, earnings equal operating cash flow, so that current earnings represent the (levered) cash flow from prior investments. In this case, higher current earnings imply higher retained earnings and an equal immediate increment to cash balances. Cash dividends also impact both retained earnings and cash equally. Cash balances, unlike retained earnings, are also affected when the firm makes capital outlays or issues or redeems debt, i.e., by non-operating and non-dividend cash inflows and outflows. And so, at any point in time the two variables have no necessary empirical connection to one another, with retained earnings measuring a firm's cumulative earnings retentions and cash balances measuring the cumulative cash inflows and outflows from all its operating, financing, and investment decisions. [Empirically, the simple correlation between RE/TE and Cash/TA is 0.00 (median of annual cross-sectional correlations over 1973-2002).]

The conceptual distinction between cash balances and retained earnings raises the possibility that our logit regressions should control for the level of cash holdings when testing whether the amount of a 
firm's earned equity affects its dividend decision. The intuition for including a cash control is that, since dividends are paid in cash, low cash balances would seemingly imply a low probability of paying dividends. However, as elaborated earlier, high cash holdings do not necessarily imply a high probability of paying dividends since, e.g., they can primarily reflect the proceeds from a recent equity offer. More generally, cash holdings are endogenous (Opler, Pinkowitz, Stulz, and Williamson (1999)), e.g., high cash balances can primarily reflect a cash buildup in anticipation of an abundance of attractive investment projects. Thus high cash balances may be empirically associated with either a high or a low probability of paying dividends. Although the expected sign is ambiguous, we nonetheless include cash holdings as an explanatory variable to assess whether RE/TE remains significant when cash is included.

In Table 5, columns (3) and (4) incorporate a control for cash balances (Cash/TA) into our basic logit regressions. For ease of comparison, columns (1) and (2) repeat the table 4 findings for logit specifications that exclude cash as an explanatory variable and use SGR and NYE to control for growth and size. With Cash/TA added as an explanatory variable, RE/TE continues to have a positive and highly significant impact on the probability of paying dividends, with t-statistics that remain in the double digits. Profitability, growth, and size also remain highly significant in the directions predicted by Fama and French (2001), while the coefficient on total equity (TE/TA) is now positive and marginally significant. In these logit regressions, cash holdings are significantly negatively related to the probability of paying dividends. For our purposes, the key observation is that the impact of earned equity on the decision to pay dividends is distinct from any impact of cash balances, i.e., that RE/TE remains highly significant when we control for the level of cash holdings.

\subsection{Dividend history and the reluctance to omit dividends}

Columns (5) through (8) of table 5 incorporate as an explanatory variable the firm's prior period dividend choice, measured by an indicator variable that takes the value 1 if the firm paid dividends in the immediately prior year, and 0 otherwise. The intuition for including this variable is Lintner's (1956) finding that managers are reluctant to cut/omit dividends, which suggests that firms that paid dividends last year will likely pay them this year. There are problems with this approach (see Fama and French 
(2001, section 5.2)), most notably that using lagged dividend status as an explanatory variable introduces a logical circularity, as the resultant analysis seeks to explain a given dividend decision on the basis of other dividend decisions. And if lagged dividend status acts as an instrument for the fundamental economic determinants of the decision to pay dividends, the impact of fundamentals is more difficult to detect in regressions that include both fundamental and instrumental variables. The implication is that a fully satisfactory dividend theory should not include lagged dividend decisions as an explanatory variable. While we agree with this implication, we nonetheless re-run our logits with lagged dividend status as a further robustness check on the relation between earned equity and the decision to pay dividends.

Columns (5) through (8) of table 5 show that the coefficient on RE/TE remains positive, with tstatistics around 6.4, when prior dividend status is included as an explanatory variable. Although these tstatistics are lower than those for RE/TE reported in columns (1) through (4), they are nonetheless highly significant at conventional levels. In all cases, the coefficients on lagged dividend status are positive and exhibit very high t-values (63.40 or higher). Inclusion of lagged dividend status also leads to a large increase in $\mathrm{R}^{2}$ s, from around $35 \%$ to $60 \%$. Obviously, whether a firm paid dividends last year is a very strong predictor of whether it will pay them this year -- a result that confirms Lintner's (1956) well known finding that managers are reluctant to omit dividends. For the current study, the important implication is that, controlling for lagged dividend status (and profitability, growth, size, total equity, and cash balances), the probability that a firm pays dividends remains significantly related to the relative amount of earned equity in its capital structure.

\subsection{Retained earnings versus current and recent profitability}

Although a firm cannot have a high level of RE/TE (or RE/TA) without having earned a substantial amount over its corporate life, these ratios are not profitability measures, but rather are measures that summarize the firm's reliance on internally generated relative to external capital (external equity in the case of RE/TE, and all outside capital in the case of RE/TA). As a result, two firms with identical historical profitability can have radically different RE/TE ratios because one has raised much more external equity to fund its substantially more attractive investment opportunities. The latter firm's 
much lower RE/TE ratio is accordingly a sign of reduced potential agency problems, hence of a lower probability of paying dividends. While our earned equity and current profitability measures are conceptually distinct variables, they are theoretically related given a strong ceteris paribus qualification: holding constant the level of contributed capital and dividends, the higher the level of current earnings, the higher will be RE/TE and RE/TA.

In section 5 (table 4), we report that the addition of RE/TE to our various regression specifications results in lower estimated coefficients on ROA and lower associated t-statistics. This finding suggests that, from an empirical perspective, RE/TE does to some degree capture the impact of current profitability. But any such commonality is limited, since ROA and RE/TE each exhibit highly significant coefficients in all regressions that we run. The strong independent effects of these variables reflect the fact that the simple correlation between RE/TE and ROA is only 0.19 (median of the annual cross-sectional correlations for 1973-2002). When we measure earned equity as a fraction of total assets rather than of total equity, the simple correlation between RE/TA and ROA, which share a common denominator, is a substantially higher 0.63. However, as we report in section 6.4, multivariate analysis along the lines of that in tables 4 and 5 (with RE/TA replacing RE/TE) continues to show highly significant coefficients for both variables in every regression specification, with the t-statistics on RE/TA always higher than those on RE/TE for otherwise identical specifications.

Arguably, our regressions should also include measures of recent profitability because earnings volatility may render current ROA a noisy indicator of a firm's capacity to pay dividends. Benartzi, Michaely, and Thaler (1997) report evidence that dividend changes convey information about profitability in the year before and year of the dividend change. To gauge the impact of recent profitability on our results, we re-run all of our tests with profitability (ROA) in the prior year added as an explanatory variable. For brevity, columns (9) and (10) report the details of just two of these tests, with (9) adding lagged ROA to the basic model in (2), and (10) adding lagged ROA to the broader model in (8). Comparison of (2) and (9) (and of (8) and (10)) reveals qualitatively identical findings on the impact of earned equity, with the RE/TE coefficients and t-statistics very similar across models. We observe the 
same close correspondence for the other control variables, although the coefficient on current ROA is a bit lower, with the impact of profitability now spread across current and lagged ROA. We do not report details of other regressions that include lagged ROA, but these sensitivity checks are uniformly consistent with the logit regressions in tables 4 and 5 -- i.e., all indicate that profitability (ROA) and earned equity (RE/TE or RE/TA) are two distinct and statistically strong determinants of the decision to pay dividends.

\subsection{Using RE/TA in place of RE/TE to measure the relative amount of earned equity}

We next assess whether our findings continue to hold when we measure earned equity as a proportion of total assets, a benchmark that incorporates non-common stock elements of external capital. The simple correlation between RE/TE and RE/TA is 0.33 (median of annual correlations over 19732002), which raises the possibility that replacing the total equity benchmark with a total assets benchmark might lead to markedly different findings. In this paper, we emphasize results based on RE/TE because RE/TA includes potentially confounding elements of debt policy (via the TA denominator). However RE/TA, the amount of internal capital relative to external capital of all types, can also be a useful measure of managerial discretion, and our theoretical discussion does not provide definitive arguments to select RE/TE over RE/TA.

Table 6 replicates the logit regressions of table 5, with the sole exception that RE/TA replaces RE/TE. In every specification in table 6, the t-statistic on RE/TA is in the double digits and is greater than the t-statistic on RE/TE in the corresponding specification in table 5. Profitability, size, growth, and cash holdings all remain highly significant as before. The results do differ in that the impact of TE/TA is negative throughout table 6 , and it was positive in four of six specifications in table 5 . In any case, the variation in the coefficients on TE/TA has no bearing on our central research question. Rather, the important bottom line here is that, like our earlier analysis based on RE/TE, the logit regressions with RE/TA uniformly and strongly support the notion that a firm's decision to pay dividends depends on the amount of earned equity in its capital structure.

\subsection{Accounting-induced measurement error and repurchase activity}

In section 3, we discuss how the accounting treatment of stock repurchases can introduce 
measurement error into RE/TE and RE/TA. Since stock repurchases increased markedly in the mid1980s and are now economically important, we check whether our results are largely driven by dividend behavior in the pre-repurchase era. To do this, we split our sample period in half, under the assumption that 1973-1987 roughly approximates the pre-repurchase era, while 1988-2002 approximates the high repurchase era. Separate logits for each sub-period (not reported) uniformly show highly significant coefficients on earned equity. Tellingly, although the t-statistics are always highly significant in the predicted direction, they are virtually always markedly higher for the first half of our sample period. [For example, for specification (4) in table 5, the t-statistics on RE/TE are 18.87 for the first half, versus 10.73 for the second half.] The strong tendency across all model specifications toward lower t-statistics in the second half of our sample period suggests that measurement error due to increased stock repurchases materially affects our later results. Nevertheless, this effect is not so substantial as to render indetectable the impact of earned equity on the dividend decision, since our tests continue to show a highly significant relation during the recent boom in stock repurchases, and therefore our inferences remain unchanged.

\subsection{Dividend initiations and omissions}

As a final robustness check on our findings that the relative amount of earned equity affects the decision to pay dividends, we check whether it and our other explanatory variables are important determinants of the decisions to initiate or omit dividends. Specifically, we expect earned equity, size, and profitability to trend upward (and growth, if anything, to slow) in the years before dividend initiations, and the opposite trends before dividend omissions. We expect logit analyses of the initiation and omission decisions to show statistical relations for all variables in the same direction as we observe in cross section for the full sample. We define a dividend initiator as a firm that pays dividends after having not paid them for at least the prior five years, and a dividend omitter as a firm that fails to pay dividends after five or more consecutive years of paying them. Within our full sample, we identify 823 firms that initiated dividends during 1973-2002, of which 22 satisfy our initiation criterion more than once (by paying dividends two or three separate times after five years of not paying them). We also identify 987 dividend-omitting firms, of which 56 satisfy our omission criterion more than once. 
Figure 1 plots the trends in the median values of RE/TE for dividend initiators and omitters over year -5 through year 0 , the year of the initiation or omission. Table 7 reports the median level of RE/TE, RE/TA, TE/TA, firm size, profitability, growth, and cash holdings for initiators (panel A) and omitters (panel B) in year -5 through year 0 . [Figure 1 and table 7 include only the first dividend initiation for the 22 firms that satisfy our initiation criterion multiple times, and the last omission for the 56 firms that satisfy that criterion multiple times.] The median RE/TE trends in Figure 1 are as expected, with dividend initiators showing an increase and omitters showing a decrease beginning in year -2 . Panel A of table 7 shows positive trends in RE/TE, RE/TA, size, and profitability (and stable sales growth, SGR) over the five years before the dividend initiation, while panel B shows deterioration in RE/TE, RE/TA, size, and profitability for omitters. Growth actually turns negative for omitters in years -1 and 0 , reflecting the seriously troubled condition of many dividend-omitting firms.

The levels of these variables in the initiation or omission year are reasonable compared to those for payers and nonpayers in the full sample (all data for the latter two groups come from table 2). For the median initiator, RE/TE is 0.557 in the initiation year, an increase from 0.406 five years earlier, but still below the 0.748 for the typical dividend payer in the full sample. For the median omitter, RE/TE erodes from 0.673 in year -5 to 0.527 in year 0 . A similar pattern holds for RE/TA, with the median of 0.247 in the initiation year up from 0.175 five years earlier, yet still below the 0.341 for the median payer in the full sample. For omitters, the median RE/TA declines from 0.302 in year -5 to 0.163 in year 0 . For the median initiator, the NYSE equity value percentile increases from NYE of 0.055 in year -5 to 0.113 in the initiation year, and the latter figure falls between the median values for payers and nonpayers (NYE = 0.302 and 0.026 respectively). Again, the opposite holds for omitters, with NYE falling from 0.164 in year -5 to 0.069 in year 0 . In sum, the typical initiator and the typical omitter both fall in the middle ground between the typical nonpayer (with low earned equity and smaller size) and the typical payer (with high earned equity and larger size).

We run logit regressions to analyze the decision to initiate (or omit) dividends as a function of earned equity, total equity, profitability, cash balances, and the combinations of size and growth measures 
described in table 4. For each year 1973-2002, our initiation logits seek to explain which of the firms in our full sample that have not paid dividends for at least five years will start paying them, with FamaMacBeth t-statistics calculated from the time series of estimated coefficients. We also run logits that seek to explain which firms stop paying dividends out of the subset of firms in our full sample that have paid them for the last five years. In our omission logits, we use RE/TA and not RE/TE because of a concern that extreme TE values for troubled firms might warp results based on RE/TE. For brevity, we simply summarize the main findings. Most importantly, earned equity remains highly significant in all logit specifications, with the lowest t-statistic equal to 5.72. As measured by pseudo $\mathrm{R}^{2} \mathrm{~s}$, the overall explanatory power of the initiation logits is markedly lower than that of the full sample logits (around 4.0\% versus $35.0 \%$ ), but these models do a good job identifying initiators or non-initiators, with about $95 \%$ on average of the observations classified correctly. The omission logits do a little better, with pseudo $\mathrm{R}^{2} \mathrm{~s}$ of around $7.0 \%$ or $8.0 \%$, and about $97 \%$ on average of observations classified correctly.

\section{Economic significance of the impact of earned equity on the probability of paying dividends}

Table 8 provides data to help assess the economic significance of earned equity, size, profitability, and growth in the decision to pay dividends. To construct the table, we estimate the probability that a firm will pay dividends as RE/TE varies across three types of firms that personify the view advanced by Fama and French (2001), Grullon, Michaely, and Swaminathan (2002) and others that dividends are paid by high profitability/low growth firms and avoided by low profitability/high growth firms. We obtain the probabilities from specification (4) of table 5, which measures earned equity by RE/TE, and which controls for size, profitability, and growth as well as for cash balances and total equity. In constructing the table, we assume that all firms have reasonably typical values of total equity and cash $(\mathrm{TE} / \mathrm{TA}=0.50$ and Cash/TA $=0.05)$. Panel A reports the estimated probability of paying dividends for low profitability/high growth firms $(\mathrm{ROA}=0.02$ and $\mathrm{SGR}=0.15)$, while panel $\mathrm{C}$ reports estimates for high profitability/low growth firms $(\mathrm{ROA}=0.12$ and $\mathrm{SGR}=0.05)$. Panel $\mathrm{B}$ provides the same information for firms with intermediate levels of profitability and growth (ROA $=0.06$ and SGR $=0.10$ ). 
Table 8 reports the estimated probability that a firm pays dividends as a function of RE/TE and firm size, holding constant TE/TA, Cash/TA, ROA, and SGR at the levels just described. Firm size is measured by the NYSE percentile ranking of its equity market value so that, e.g., the fifth row has NYE = 0.50, indicating a firm whose equity value falls at the median among NYSE industrials. The first column $(\mathrm{RE} / \mathrm{TE}=0.10)$ reports the probability of paying dividends for a firm whose equity is $10 \%$ earned and $90 \%$ contributed, the second column is for a firm with a $20 \%-80 \%$ mix of earned and contributed equity, and so on up to a $90 \%-10 \%$ mix. The column labeled "average change" contains the average change in the probability of paying dividends associated with an increase of 0.10 in RE/TE, while the row with the same label reports the average probability change associated with a one decile increase in a firm's size ranking based on equity value. ${ }^{4}$

For profitability and growth, our logit regressions show respectively a positive and negative impact on the probability of paying dividends, with both relations highly significant in a statistical sense, but table 8 shows that the economic magnitude of the these two relations is relatively modest. To see this point, select any cell in panel C (which contains data for high profitability/low growth firms) and compare its estimated probability of paying dividends to that for the matching cell in panel A (which contains data for low profitability/high growth firms). For example, among the panel C high profitability/low growth firms, a firm whose market value is at the median ( $\mathrm{NYE}=0.50$ ), with an equal split of internal and external equity $(\mathrm{RE} / \mathrm{TE}=0.50)$, has a 0.734 estimated probability of paying dividends, which exceeds by 0.050 the 0.684 probability estimate for an otherwise identical low profitability/high growth firm in panel A. A comparison of any cell in panel $\mathrm{C}$ with the corresponding entry in panel A shows a similar modest probability difference, indicating that large differences in current profitability and growth translate to economically modest differences in the estimated probability of paying dividends.

Size differences are associated with substantial differences in the probability of paying dividends.

\footnotetext{
${ }^{4}$ The former average is the probability of paying dividends implied by RE/TE $=0.90$ minus the probability implied by $\mathrm{RE} / \mathrm{TE}=0.10$, divided by 8 (the number of intervals of size 0.10 between the two values). The latter average is the probability of paying dividends implied by NYE $=0.90$ minus the probability implied by NYE $=0.10$, divided by 8 (the number of deciles between $10^{\text {th }}$ and $90^{\text {th }}$ percentiles).
} 
Scanning down each column in any given panel of table 8 shows that a firm at the $10^{\text {th }}$ percentile for equity value $(\mathrm{NYE}=0.10$ ) has a much lower probability of paying dividends than a firm at the median, which in turn has a much lower probability than a firm at the $90^{\text {th }}$ percentile. According to the bottom row, which reports the average change from the $10^{\text {th }}$ to $90^{\text {th }}$ percentiles, a one decile difference in equity value rank translates to an average probability difference of as much as 0.076 (when RE/TE is low) to a still substantial 0.043 (when RE/TE is high). These data show that the very largest firms exhibit a substantially higher probability of paying dividends than do firms that rank in the middle or at the low end of the NYSE equity value spectrum, after controlling for profitability, growth, the relative amount of earned equity, etc.

RE/TE differences are associated with substantial differences in the probability of paying dividends for all but the highest size deciles of NYSE firms, with smaller yet nontrivial increases for the latter firms. Our finding that the impact of RE/TE is less marked for the largest firms is a manifestation of the fact that the unconditional probability of paying dividends is quite high among this group. For firms with average current profitability and growth (panel B) whose equity value matches that of the median NYSE firm $(\mathrm{NYE}=0.50)$, an increase from $\mathrm{RE} / \mathrm{TE}=0.10$ to $\mathrm{RE} / \mathrm{TE}=0.90$ increases the probability of paying dividends by $0.355(0.856-0.501)$, which is a .044 increase for each increment of 0.10 in RE/TE. For the purpose of explaining whether a firm pays dividends or not, the economic impact of the amount of earned equity in its capital structure -- like that of its size -- is clearly substantial, and the impact of both earned equity and size are much greater than those of profitability and growth.

\section{8. $\quad$ Conclusion}

Why do firms pay dividends? The answer becomes apparent when one considers what their asset and capital structures would eventually look like if they did not, and the potential agency problems those asset and capital structures would engender. For the 25 largest long-standing dividend payers in 2002, we document that a decision to retain earnings instead of paying dividends would result in firms with little or no long-term debt and enormous cash balances that far outstrip any reasonable estimate of their attractive 
investment opportunities. If, as agency theory assumes, large-scale retention facilitates non-value maximizing behavior by managers (Jensen (1986)), then dividends are valuable for these firms because they help avoid asset/capital structures that give managers wide discretion to make value-reducing investments. When the potential costs of excess retention are considered jointly with factors that encourage retention (e.g., flotation costs and personal taxes), the testable prediction is that firms avoid dividends when earned capital is low (relative to contributed capital) and pay them only after generating substantial earned equity (sufficient both to fund profitable projects and to sustain an ongoing stream of dividends). Our evidence uniformly and strongly supports this view of dividend policy.

For publicly traded industrials over 1973-2002, the proportion that pays dividends is high when the ratio of earned equity to total common equity (or to total assets) is high, and falls with declines in either ratio, becoming near zero when a firm has little or no earned equity. In a broad set of multivariate logit tests, we consistently observe a highly significant relation between the decision to pay dividends and the ratio of earned equity to total equity (and to total assets), controlling for firm size, current and recent profitability, growth, leverage, cash balances, and dividend history. The relation between earned equity and the decision to pay dividends is economically, as well as statistically significant, with the difference between high and low values of earned equity translating to a substantial difference in the probability of paying dividends for all but the largest NYSE firms (for which the probability difference is smaller, but still nontrivial, because the unconditional probability of paying dividends is high for very large firms). In fact, earned equity has an economically more important impact on the dividend decision than do profitability or growth, variables emphasized in the empirical payout literature. Overall, our evidence supports the hypothesis that firms pay dividends to mitigate the agency costs associated with the high cash, low debt capital structures that would eventually result if they didn’t. 
Table 1

Inflation-adjusted dividends paid over 1950-2002 and cash holdings in 2002, in actual terms and "as if" total dividends were retained rather than distributed to stockholders: 25 industrial firms that paid dividends in 2002 and that paid the largest total dividends over 1950-2002

Columns (1) through (4) give actual values, while shaded columns (5) and (6) give hypothetical values. Total real dividends are the sum of dividends over 1950-2002 (per Compustat), with each year's payment inflation adjusted to 2002 dollars using the CPI. Cash, LTD, and TA are respectively the 2002 actual values of cash plus marketable securities, long-term debt, and total assets. To generate the "as if" value of Cash/TA in column (5), we add total real dividends over 1950-2002 to actual 2002 cash balances. To generate the “as if” values of Cash/TA in column (6), we first apply total dividends to pay down long-term debt in 2002, and add the remainder to cash balances. To generate this sample, we begin with U.S. incorporated industrial firms listed on NYSE, NASDAQ, and AMEX with CRSP share codes 10 or 11 and with nonmissing data on Compustat for dividends and earnings for 2002. Industrials are those with SIC codes outside the ranges 4900-4949 and 6000-6999 (financials and utilities). We restrict attention to firms that paid dividends in 2002 and, of these, the 25 firms listed below are those that paid the largest total real dividends over 1950-2002.

\begin{tabular}{|c|c|c|c|c|c|c|}
\hline & $(1)$ & (2) & (3) & (4) & (5) & (6) \\
\hline & $\begin{array}{c}\text { Total real } \\
\text { dividends } \\
1950-2002\end{array}$ & $\begin{array}{c}\text { Cash } \\
\text { in } 2002\end{array}$ & $\begin{array}{c}\text { LTD } \\
\text { in } 2002\end{array}$ & $\begin{array}{c}\text { Actual } \\
\text { in } 2002\end{array}$ & $\begin{array}{l}\text { As if all } \\
\text { retained }\end{array}$ & $\begin{array}{l}\text { As if debt } \\
\text { paid down }\end{array}$ \\
\hline & & (\$ billions) & & Cash/TA & Cash/TA & Cash/TA \\
\hline AT\&T & $\$ 232.0$ & $\$ 8.1$ & $\$ 18.8$ & 0.15 & 0.84 & 0.82 \\
\hline Exxon Mobil & 208.5 & 7.2 & 6.7 & 0.05 & 0.60 & 0.59 \\
\hline General Motors & 179.6 & 21.4 & 134.3 & 0.06 & 0.36 & 0.16 \\
\hline IBM & 107.9 & 6.0 & 20.0 & 0.06 & 0.56 & 0.51 \\
\hline General Electric & 103.3 & 16.7 & 140.6 & 0.03 & 0.18 & 0.03 \\
\hline Du Pont & 74.2 & 4.1 & 5.6 & 0.12 & 0.72 & 0.70 \\
\hline Ford Motor & 64.2 & 30.5 & 125.8 & 0.10 & 0.26 & 0.10 \\
\hline ChevronTexасо & 64.1 & 3.8 & 10.9 & 0.05 & 0.48 & 0.44 \\
\hline Altria & 61.6 & 0.6 & 21.4 & 0.01 & 0.42 & 0.32 \\
\hline Sears Roebuck & 41.4 & 2.0 & 21.3 & 0.04 & 0.47 & 0.31 \\
\hline Merck & 39.7 & 5.0 & 4.9 & 0.10 & 0.51 & 0.48 \\
\hline Eastman Kodak & 39.6 & 0.6 & 1.2 & 0.04 & 0.76 & 0.75 \\
\hline Verizon & 37.8 & 3.5 & 44.8 & 0.02 & 0.20 & 0.02 \\
\hline Procter \& Gamble & 35.8 & 3.6 & 11.2 & 0.09 & 0.51 & 0.43 \\
\hline Coca-Cola & 33.4 & 2.3 & 2.7 & 0.10 & 0.62 & 0.60 \\
\hline SBC & 32.6 & 3.6 & 18.5 & 0.04 & 0.28 & 0.16 \\
\hline Bristol Myers Squibb & 31.3 & 4.0 & 6.3 & 0.16 & 0.63 & 0.58 \\
\hline BellSouth & 30.5 & 2.5 & 12.3 & 0.05 & 0.41 & 0.31 \\
\hline Wyeth & 30.2 & 5.5 & 7.5 & 0.21 & 0.63 & 0.58 \\
\hline $3 \mathrm{M}$ & 28.6 & 0.6 & 2.1 & 0.04 & 0.67 & 0.65 \\
\hline Dow Chemical & 28.4 & 1.6 & 11.7 & 0.04 & 0.44 & 0.33 \\
\hline Pfizer & 25.1 & 12.6 & 3.1 & 0.27 & 0.53 & 0.50 \\
\hline Johnson \& Johnson & 22.8 & 7.5 & 2.0 & 0.18 & 0.48 & 0.46 \\
\hline ITT & 22.1 & 0.2 & 0.5 & 0.04 & 0.81 & 0.81 \\
\hline Lilly (Eli) & 21.7 & 3.7 & 4.4 & 0.19 & 0.62 & 0.58 \\
\hline Total dollar amount & $\$ 1,596.5$ & $\$ 157.0$ & $\$ 638.6$ & & & \\
\hline Median ratio & & & & 0.06 & 0.51 & 0.48 \\
\hline
\end{tabular}


Table 2

\section{Median measures of earned equity and related descriptive statistics for industrial firms on CRSP/Compustat: 1973-2002}

For each year over 1973-2002, the sample consists of (U.S.-incorporated and NYSE, NASDAQ, and AMEX-listed) industrial firms with CRSP share codes 10 or 11 and nonmissing data on Compustat for dividends and earnings before extraordinary items. We first calculate the median value within each year and then take the median across all sample years to obtain the figures reported in the table. The ratio of earned equity to total common equity (RE/TE) is calculated for those firms with positive total equity, and equals retained earnings divided by the total book value of common stockholders' equity. Earned equity to total assets (RE/TA) is the ratio of retained earnings to total assets. The asset growth rate (AGR) is the change in total assets divided by the previous year's level, while the sales growth rate (SGR) is defined analogously with respect to revenue. The market value of equity is based on CRSP share prices and quantities closest to year-end. The market-to-book ratio equals the market value of equity plus book assets minus book equity, all divided by total assets. Profitability is measured as the return on assets (ROA), and equals earnings before extraordinary items plus interest expense plus deferred taxes from the income statement (if available), all divided by total assets. Our equity value measure (NYE) equals the percentile (expressed in fractional form) in which the firm falls based on the full cross-sectional distribution of the market value of equity for NYSE companies. Our asset size measure (NYA) is defined analogously relative to the full distribution of total assets for NYSE firms.

Median value for:

\begin{tabular}{lcc} 
& Dividend payers & Nonpayers \\
\hline 1. Earned equity to total common equity (RE/TE) & 0.748 & 0.037 \\
2. Earned equity to total assets (RE/TA) & 0.341 & -0.015 \\
3. Total common equity to total assets (TE/TA) & 0.480 & 0.470 \\
4. Profitability (ROA) & 0.086 \\
5. Sales growth rate (SGR) & 0.134 \\
6. Asset growth rate (AGR) & 0.086 & 0.075 \\
7. Market-to-book ratio (M/B) & 0.086 & 1.4 \\
8. NYSE asset percentile (NYA) & 1.3 & 0.005 \\
9. NYSE equity value percentile (NYE) & 0.302 & 0.026 \\
10. Cash to total assets (Cash/TA) & 0.362 & 3,015 \\
\hline 11. Number of firms & 0.052 & 0.082 \\
\hline
\end{tabular}




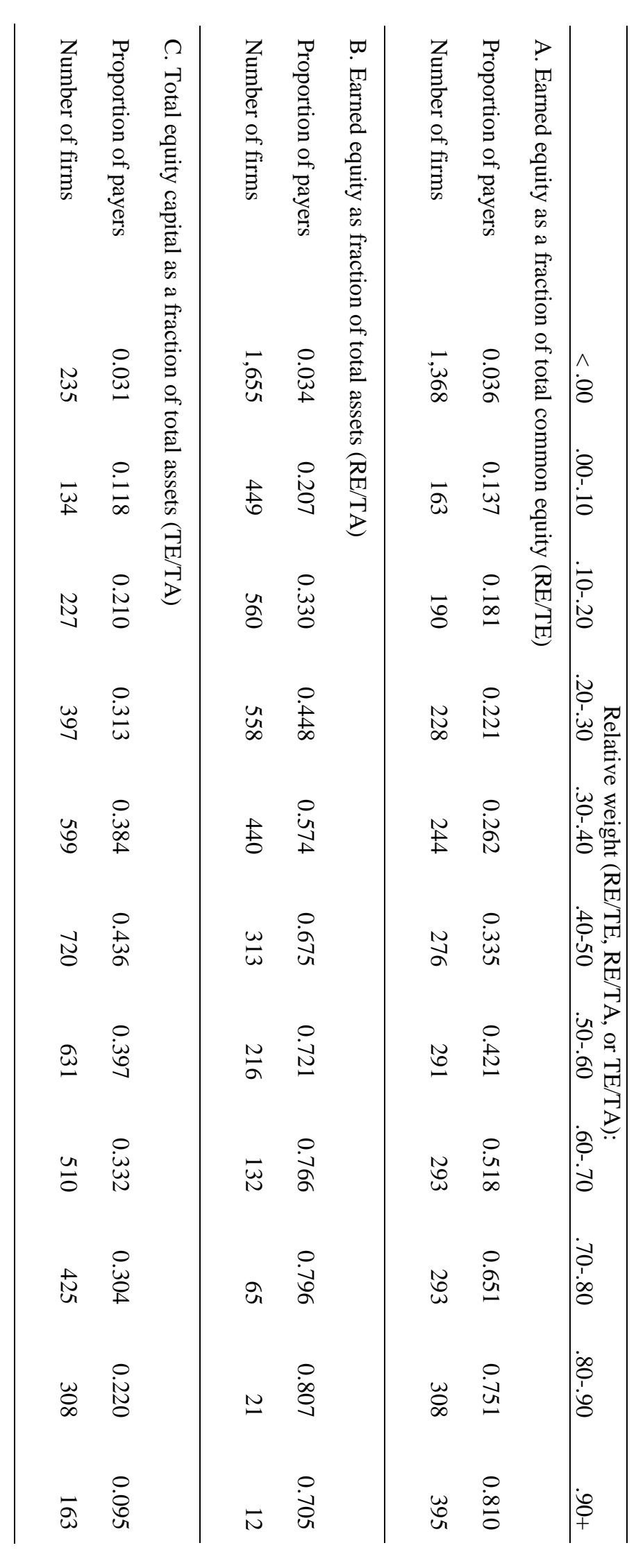

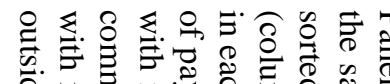

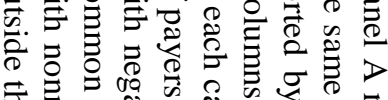

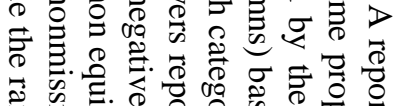

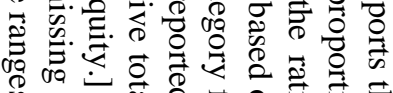

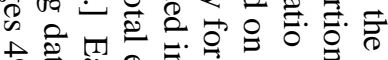

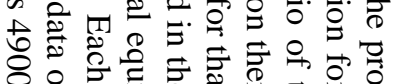

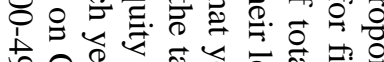

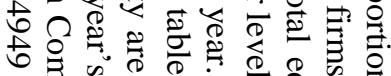

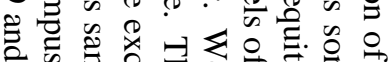

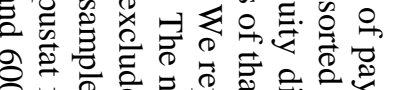

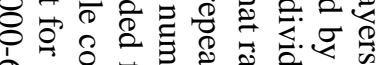

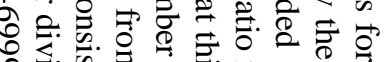

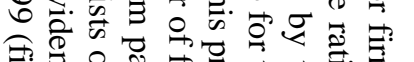

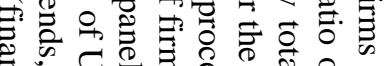

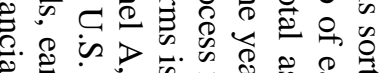

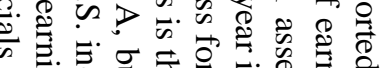

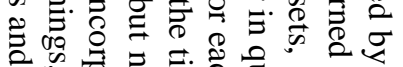

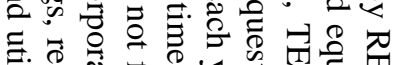

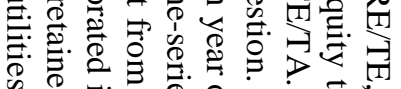
क्ठ

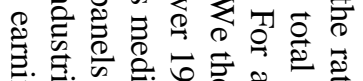

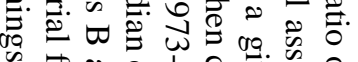

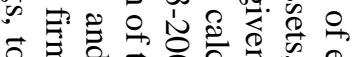

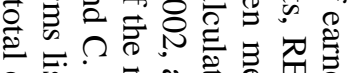

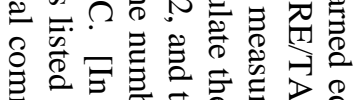

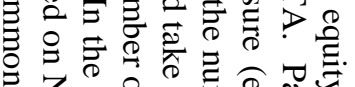

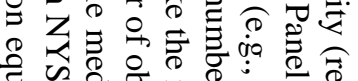

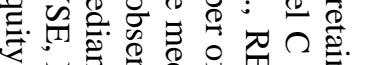

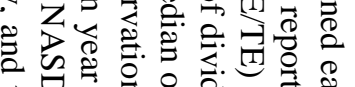

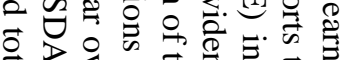

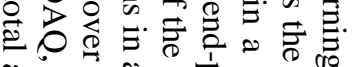

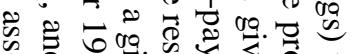

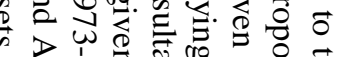

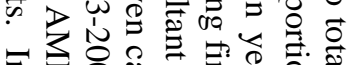

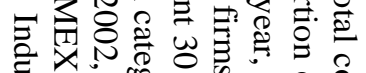

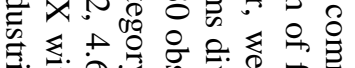

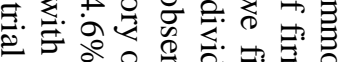

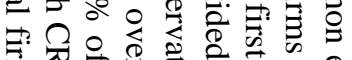

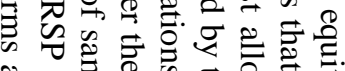

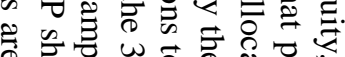

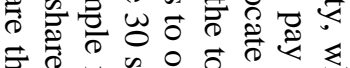

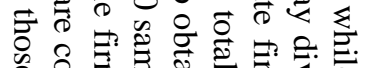

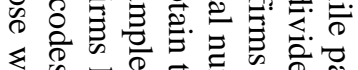

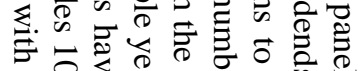

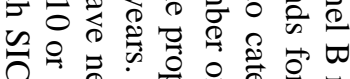

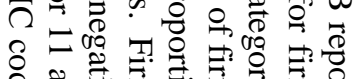

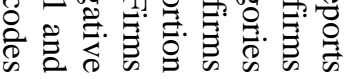




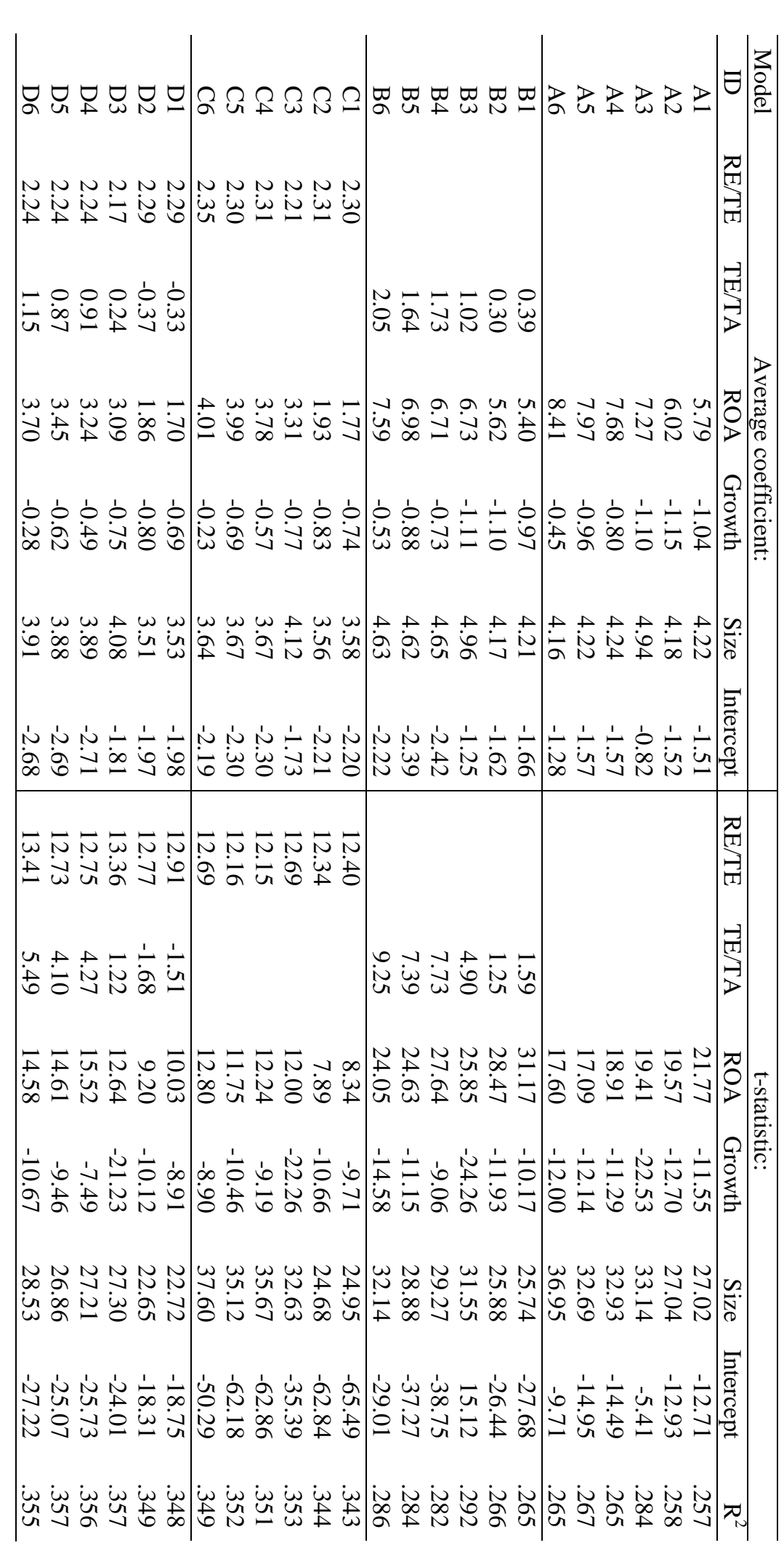

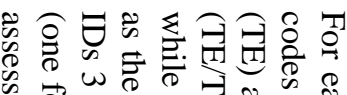

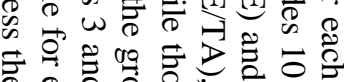

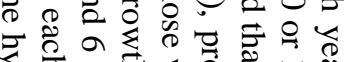

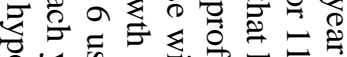

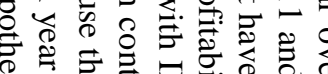

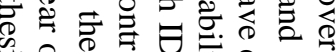
心.

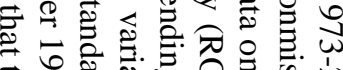

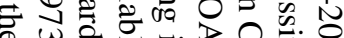
D

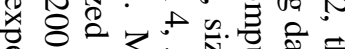

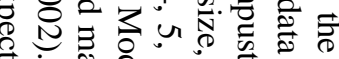

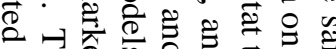

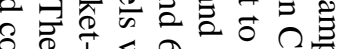

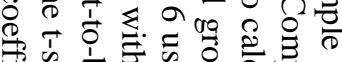

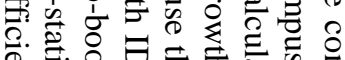

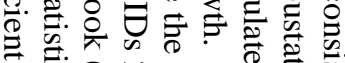

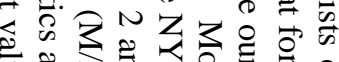

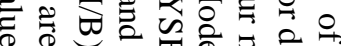

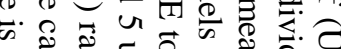

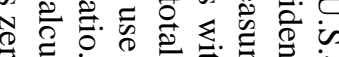

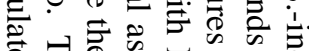

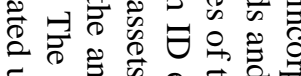

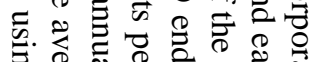

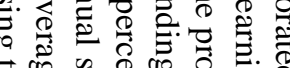

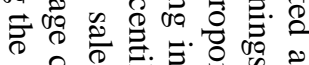

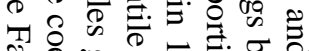

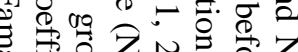

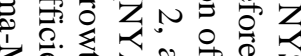

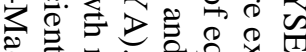

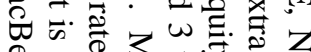

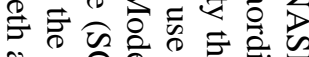

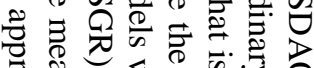

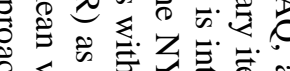

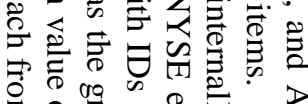

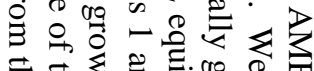

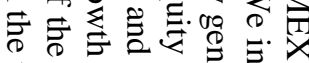

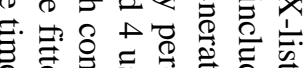

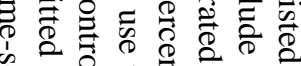

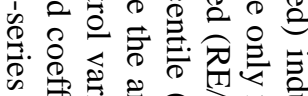

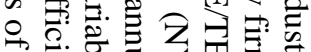

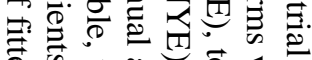

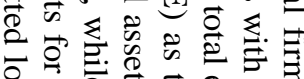

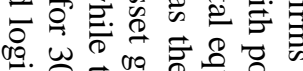

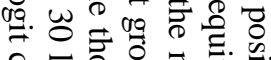
ᄋి o

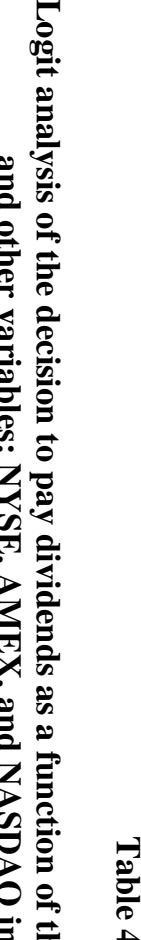

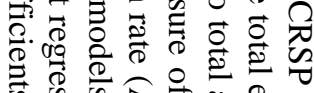

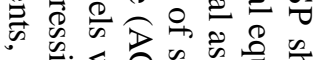

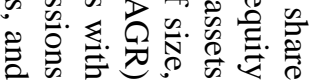




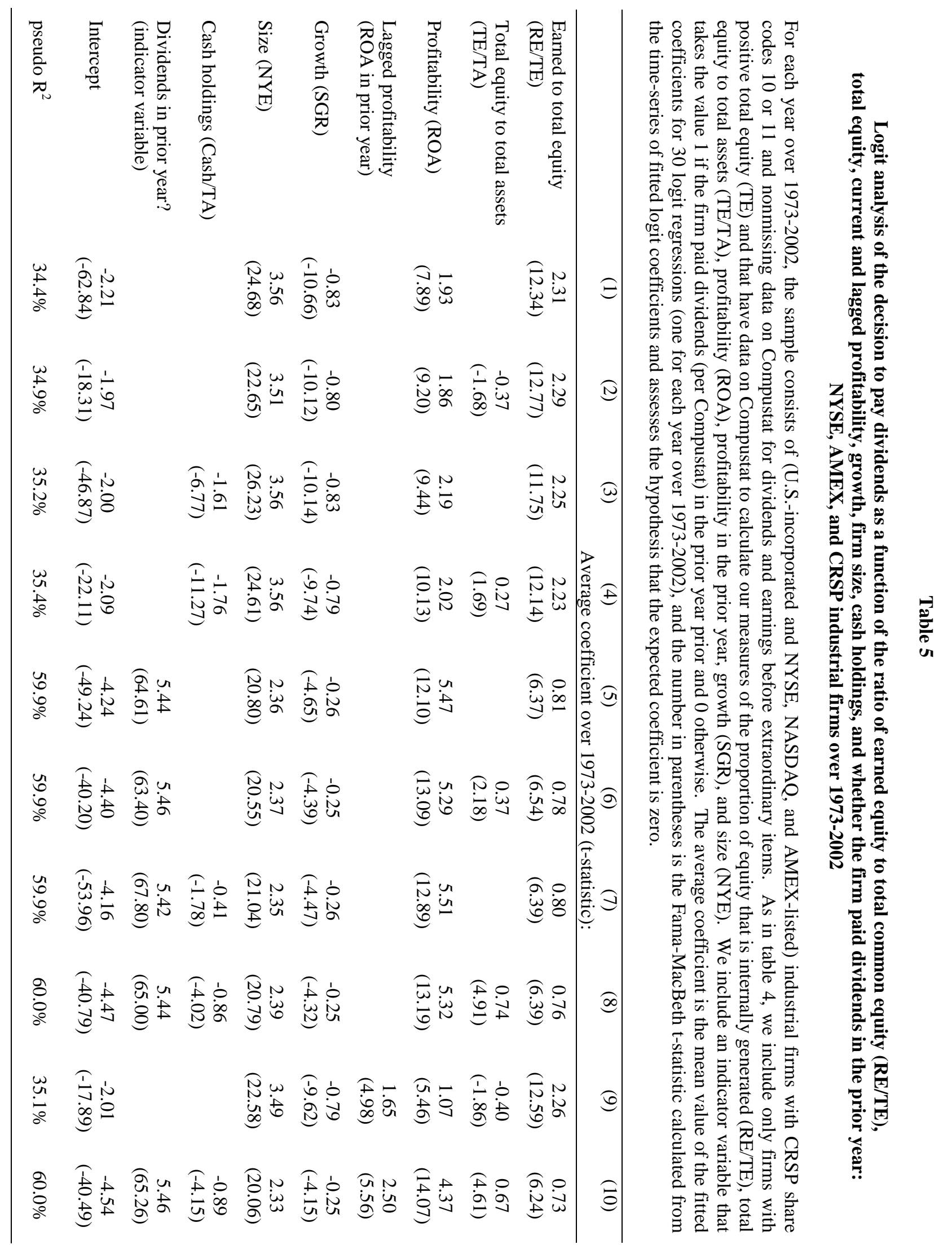




\begin{tabular}{|c|c|c|c|c|c|c|c|c|c|}
\hline 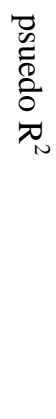 & 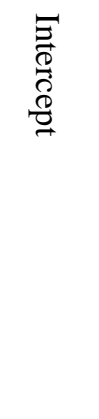 & 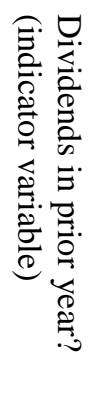 & 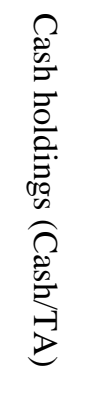 & 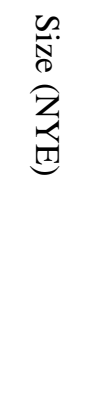 & $\begin{array}{l}0 \\
0 \\
\sum^{0} \\
\equiv \\
0 \\
0 \\
0\end{array}$ & 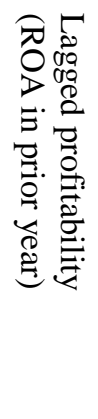 & 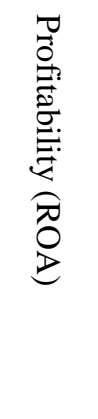 & 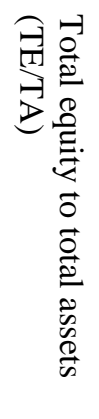 & 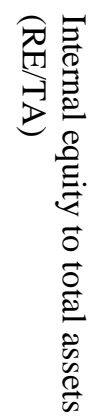 \\
\hline $\begin{array}{l}\omega \\
\stackrel{+}{\omega} \\
\stackrel{0}{\circ}\end{array}$ & 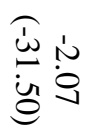 & & & 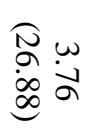 & 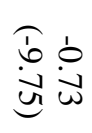 & & 它官 & & 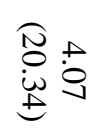 \\
\hline $\begin{array}{l}\omega \\
\sigma \\
\frac{1}{0} \\
\partial^{\circ}\end{array}$ & 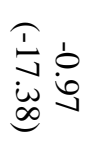 & & & 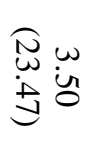 & 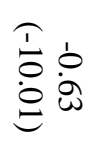 & & $\begin{array}{l}\text { जि } \\
\stackrel{0}{0}:\end{array}$ & 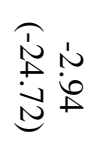 & 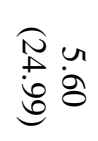 \\
\hline $\begin{array}{l}\omega \\
\sigma \\
\circ \\
0\end{array}$ & 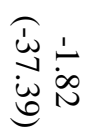 & & 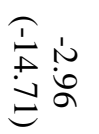 & 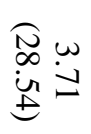 & 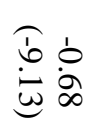 & & 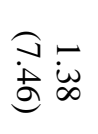 & & $\begin{array}{l}\widehat{N} \\
\dot{\omega} \\
\dot{\omega} \\
\dot{G}\end{array}$ \\
\hline $\begin{array}{l}\omega \\
\sigma \\
\infty \\
0 \\
0\end{array}$ & 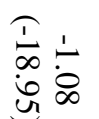 & & 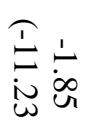 & 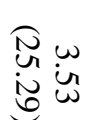 & 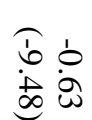 & & कि & 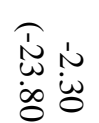 & 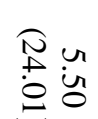 \\
\hline $\begin{array}{l}8 \\
\circ \\
0 \\
\circ\end{array}$ & 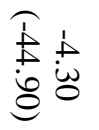 & 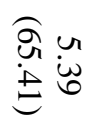 & & 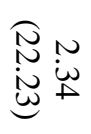 & $\begin{array}{l}\text { ID } \\
\dot{0} \\
\dot{\omega}\end{array}$ & & 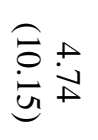 & & $\begin{array}{l}\overparen{\omega} \\
\dot{\vec{\theta}} \\
\dot{\omega}\end{array}$ \\
\hline $\begin{array}{l}\text { 영 } \\
\circ \\
\circ\end{array}$ & 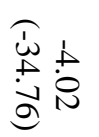 & 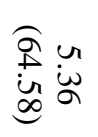 & & 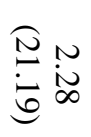 & 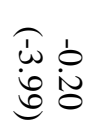 & & 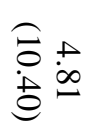 & $\begin{array}{l}\text { I } \\
\dot{1} \\
\dot{8}\end{array}$ & $\begin{array}{l}\overparen{\omega} \\
\dot{\omega} \\
\dot{\vec{\omega}} \\
\vec{\omega}\end{array}$ \\
\hline $\begin{array}{l}8 \\
\circ \\
\circ \\
\circ\end{array}$ & 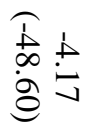 & 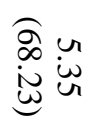 & 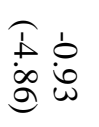 & 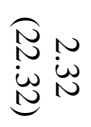 & 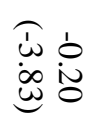 & & 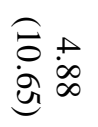 & & 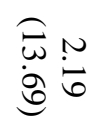 \\
\hline $\begin{array}{l}\stackrel{8}{\circ} \\
\stackrel{0}{\circ}\end{array}$ & 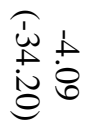 & 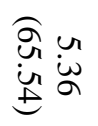 & 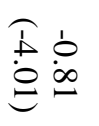 & 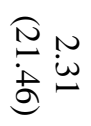 & 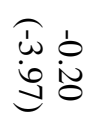 & & 灾 & İ & 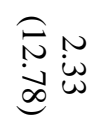 \\
\hline $\begin{array}{l}\omega \\
\text { ब } \\
\text { uा } \\
0\end{array}$ & 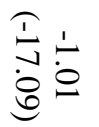 & & & 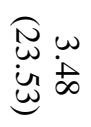 & $\begin{array}{l}1 \\
1 \\
\dot{9} \\
\dot{0}\end{array}$ & 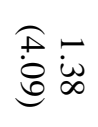 & 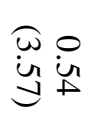 & 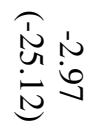 & 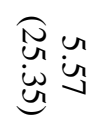 \\
\hline $\begin{array}{l}\stackrel{8}{\circ} \\
\frac{0}{0}\end{array}$ & 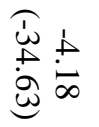 & 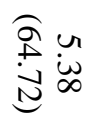 & 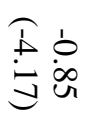 & 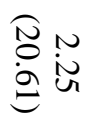 & جُ & $\begin{array}{l}\text { I } N \\
\dot{\mathscr{C}} \tilde{\omega}\end{array}$ & 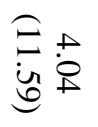 & 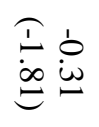 & $\begin{array}{l}\stackrel{\vec{N}}{N} \\
\dot{\omega} \\
\stackrel{N}{ \pm}\end{array}$ \\
\hline
\end{tabular}

氙

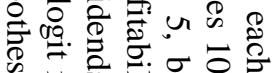

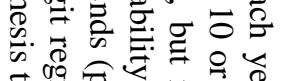

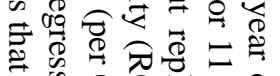

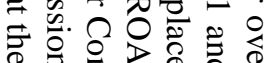
क क

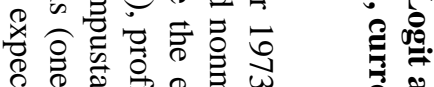

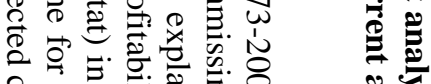
ᄋ

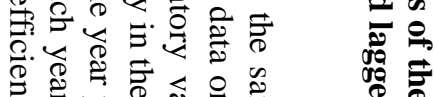

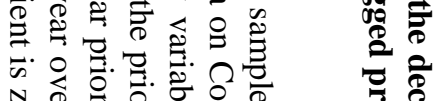

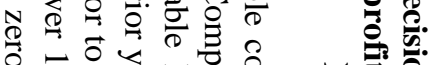

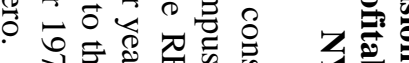

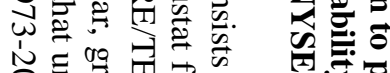

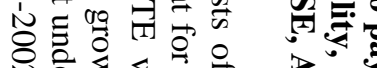

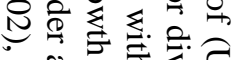

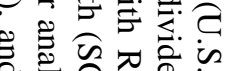

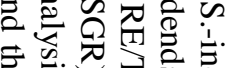

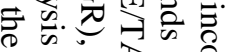
产爱? 范

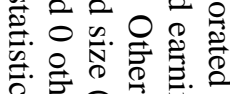

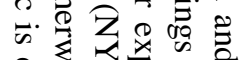

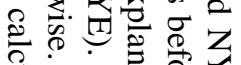

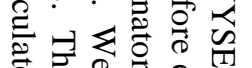

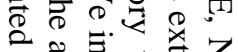

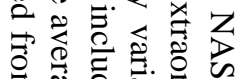

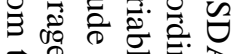

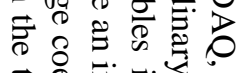

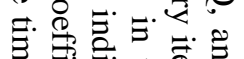

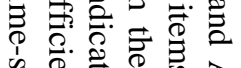

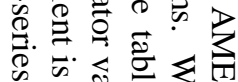
虽客思.

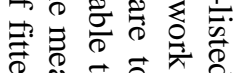

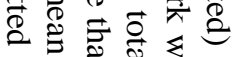

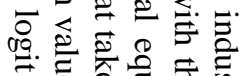

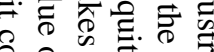
ᄋ요월

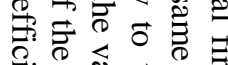

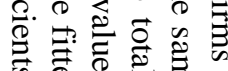

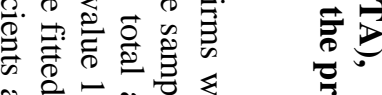

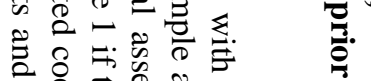

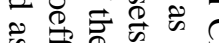

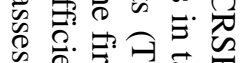

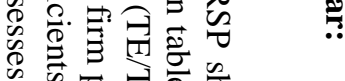

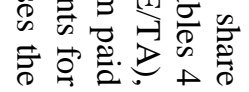
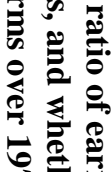

可

哭吾通

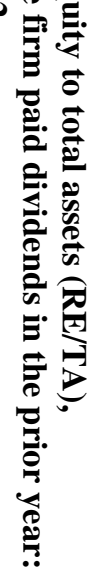

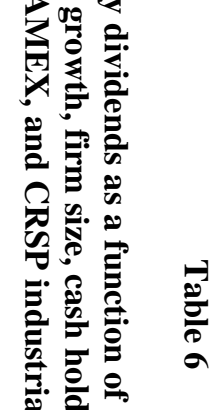




\section{Figure 1}

\section{Trend in Median RE/TE Beginning Five Years Prior to Dividend Initiations and Omissions}

$\mathrm{RE} / \mathrm{TE}$ is the ratio of retained earnings to total common equity. The initiation sample consists of 823 industrial firms that initiated dividends after paying zero dividends for at least five consecutive years. For the 22 firms that satisfy this sampling condition more than once during 1973-2002, the figure includes only the first dividend initiation. The omission sample consists of 987 firms that failed to pay a dividend after at least five consecutive years of paying them. For the 56 firms that satisfy this sampling condition more than once during 1973-2002, the figure includes only the last dividend omission. Event year 0 is the year of initiation (or omission), event year -1 is the immediately prior year, and so on.

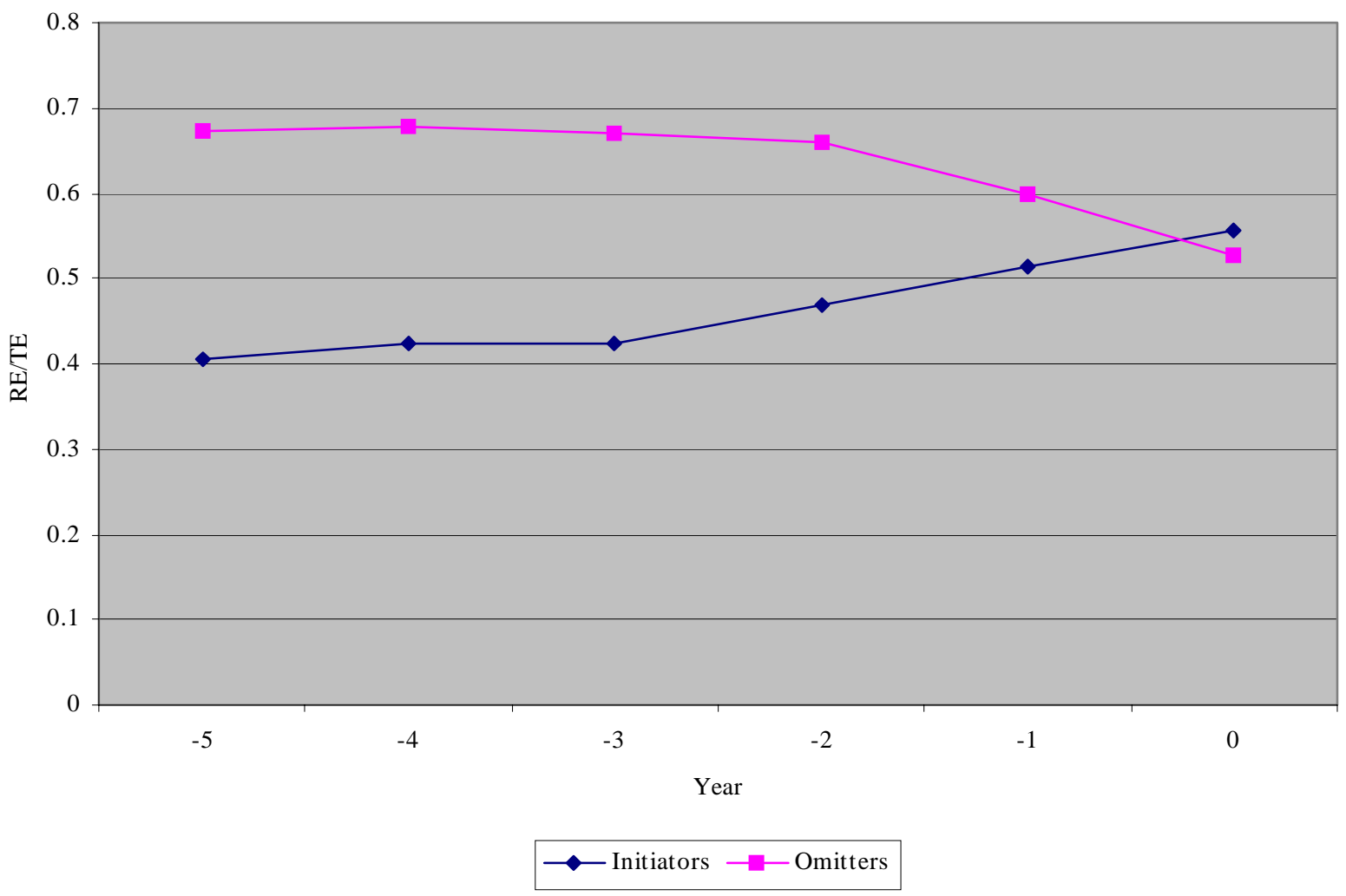


Table 7

\section{Median ratio of earned equity to total common equity (RE/TE) and other determinants of the decision to pay dividends in the years leading up to dividend initiations and omissions by CRSP/Compustat industrials over 1973-2002}

The initiation sample consists of 823 industrial firms that initiated dividends after paying zero dividends for at least five consecutive years. For the 22 firms that satisfy this sampling condition more than once during 1973-2002, the table includes only the first dividend initiation. The omission sample consists of 987 firms that failed to pay a dividend after at least five consecutive years of paying them. For the 56 firms that satisfy this sampling condition more than once during 1973-2002, the table includes only the last dividend omission. Event year 0 is the year of initiation (or omission), event year -1 is the immediately prior year, and so on.

\section{A. Dividend initiations}

\begin{tabular}{lcccccc}
\hline & \multicolumn{7}{c}{ Median level in specified event year relative to initiation in year 0: } \\
& -5 & -4 & -3 & -2 & -1 & 0 \\
\hline Earned equity to total equity (RE/TE) & 0.406 & 0.423 & 0.424 & 0.469 & 0.514 & 0.557 \\
Earned equity to total assets (RE/TA) & 0.175 & 0.169 & 0.179 & 0.194 & 0.230 & 0.247 \\
Total equity to total assets (TE/TA) & 0.457 & 0.450 & 0.453 & 0.463 & 0.495 & 0.500 \\
Size (NYE) & 0.055 & 0.057 & 0.056 & 0.070 & 0.091 & 0.113 \\
Profitability (ROA) & 0.072 & 0.073 & 0.074 & 0.076 & 0.090 & 0.094 \\
Growth (SGR) & 0.139 & 0.133 & 0.114 & 0.123 & 0.156 & 0.136 \\
Cash holdings (Cash/TA) & 0.059 & 0.059 & 0.060 & 0.070 & 0.079 & 0.075 \\
\hline
\end{tabular}

\section{B. Dividend omissions}

Median level in specified event year relative to omission in year 0:

\begin{tabular}{lcccccc} 
& -5 & -4 & -3 & -2 & -1 & 0 \\
\hline Earned equity to total equity (RE/TE) & 0.673 & 0.678 & 0.671 & 0.659 & 0.598 & 0.527 \\
Earned equity to total assets (RE/TA) & 0.302 & 0.298 & 0.281 & 0.258 & 0.202 & 0.163 \\
Total equity to total assets (TE/TA) & 0.483 & 0.476 & 0.452 & 0.423 & 0.368 & 0.363 \\
Size (NYE) & 0.164 & 0.170 & 0.172 & 0.129 & 0.087 & 0.069 \\
Profitability (ROA) & 0.084 & 0.080 & 0.072 & 0.057 & 0.016 & 0.025 \\
Growth (SGR) & 0.106 & 0.098 & 0.085 & 0.057 & -0.016 & -0.024 \\
Cash holdings (Cash/TA) & 0.051 & 0.048 & 0.044 & 0.036 & 0.034 & 0.043 \\
\hline
\end{tabular}


Table 8

\section{Probability that a firm pays dividends as a function of earned equity and firm size: Estimates based on median fitted logit model coefficients for industrial firms over 1973-2002}

These probability estimates are based on model (4) of table 5. The size measure is NYE, the firm's percentile ranking based on the market values of equity for NYSE industrials. In all three panels, we assume that the ratio of total equity to total assets, TE/TA, equals 0.50, and that the ratio of cash to total assets, Cash/TA, equals 0.05 . In panel A, the sales growth rate, SGR, is set equal to 0.15 , while profitability, ROA, is set equal to .02. In panel B, $\mathrm{SGR}=0.10$ and $\mathrm{ROA}=0.06$. In panel $\mathrm{C}, \mathrm{SGR}=0.05$ and $\mathrm{ROA}=0.12$. The column labeled "average change" gives the change in probability from the first column to the last, divided by 8 (the number of increments of 0.10 between $\mathrm{RE} / \mathrm{TE}=0.10$ and $\mathrm{RE} / \mathrm{TE}=0.90$ ). The interpretation is that, over the full interval from $\mathrm{RE} / \mathrm{TE}=0.10$ to 0.90 , an increment of 0.10 in this ratio translates to the specified average change in the probability that a firm pays dividends. Similarly, each row labeled "average change” gives the change in probability from the first row to the last, divided by 8 (the number of deciles between the first and ninth).

\section{A. Low profitability and high growth $(\mathrm{ROA}=0.02$ and $S G R=0.15)$}

\begin{tabular}{|c|c|c|c|c|c|c|c|c|c|c|}
\hline \multirow{2}{*}{$\begin{array}{c}\text { Size } \\
\text { percentile } \\
\text { NYE }\end{array}$} & \multicolumn{9}{|c|}{ Retained earnings to total equity (RE/TE): } & \multirow{2}{*}{$\begin{array}{l}\text { Avg. } \\
\text { change }\end{array}$} \\
\hline & .10 & .20 & .30 & .40 & .50 & .60 & .70 & .80 & .90 & \\
\hline .10 & 0.176 & 0.211 & 0.250 & 0.295 & 0.343 & 0.395 & 0.449 & 0.505 & 0.560 & 0.048 \\
\hline .20 & 0.234 & 0.276 & 0.323 & 0.374 & 0.427 & 0.482 & 0.538 & 0.593 & 0.645 & 0.051 \\
\hline .30 & 0.304 & 0.353 & 0.405 & 0.460 & 0.515 & 0.571 & 0.624 & 0.675 & 0.722 & 0.052 \\
\hline .40 & 0.384 & 0.438 & 0.493 & 0.549 & 0.603 & 0.655 & 0.703 & 0.748 & 0.787 & 0.050 \\
\hline .50 & 0.471 & 0.526 & 0.581 & 0.634 & 0.684 & 0.730 & 0.772 & 0.809 & 0.841 & 0.046 \\
\hline .60 & 0.559 & 0.613 & 0.665 & 0.712 & 0.756 & 0.795 & 0.829 & 0.858 & 0.883 & 0.040 \\
\hline .70 & 0.644 & 0.694 & 0.739 & 0.780 & 0.815 & 0.847 & 0.873 & 0.896 & 0.915 & 0.034 \\
\hline .80 & 0.721 & 0.764 & 0.802 & 0.835 & 0.863 & 0.887 & 0.908 & 0.925 & 0.939 & 0.027 \\
\hline .90 & 0.787 & 0.822 & 0.852 & 0.878 & 0.900 & 0.918 & 0.934 & 0.946 & 0.956 & 0.021 \\
\hline Avg. change & 0.076 & 0.076 & 0.075 & 0.073 & 0.070 & 0.065 & 0.061 & 0.055 & 0.050 & --- \\
\hline
\end{tabular}

B. Average profitability and average growth $(\mathrm{ROA}=0.06$ and $\mathrm{SGR}=0.10)$

\begin{tabular}{c|cccccccccc}
\hline .10 & 0.194 & 0.232 & 0.274 & 0.320 & 0.371 & 0.424 & 0.479 & 0.535 & 0.590 & 0.049 \\
.20 & 0.256 & 0.301 & 0.350 & 0.402 & 0.457 & 0.512 & 0.568 & 0.621 & 0.672 & 0.052 \\
.30 & 0.330 & 0.381 & 0.434 & 0.490 & 0.545 & 0.600 & 0.652 & 0.701 & 0.745 & 0.052 \\
.40 & 0.412 & 0.467 & 0.523 & 0.578 & 0.631 & 0.682 & 0.728 & 0.770 & 0.807 & 0.049 \\
.50 & 0.501 & 0.556 & 0.610 & 0.662 & 0.710 & 0.753 & 0.793 & 0.827 & 0.856 & 0.044 \\
.60 & 0.589 & 0.641 & 0.691 & 0.736 & 0.777 & 0.814 & 0.845 & 0.872 & 0.895 & 0.038 \\
.70 & 0.671 & 0.719 & 0.761 & 0.800 & 0.833 & 0.862 & 0.886 & 0.907 & 0.924 & 0.032 \\
.80 & 0.745 & 0.785 & 0.820 & 0.851 & 0.877 & 0.899 & 0.917 & 0.933 & 0.946 & 0.025 \\
.90 & 0.806 & 0.839 & 0.867 & 0.890 & 0.910 & 0.927 & 0.941 & 0.952 & 0.961 & 0.019 \\
\hline Avg. change & 0.076 & 0.076 & 0.074 & 0.071 & 0.067 & 0.063 & 0.058 & 0.052 & 0.046 & --- \\
\hline
\end{tabular}

C. High profitability and low growth $(\mathrm{ROA}=0.12$ and SGR $=0.05)$

\begin{tabular}{c|cccccccccc}
\hline .10 & 0.214 & 0.254 & 0.298 & 0.347 & 0.399 & 0.454 & 0.509 & 0.565 & 0.618 & 0.051 \\
.20 & 0.280 & 0.327 & 0.378 & 0.431 & 0.487 & 0.542 & 0.597 & 0.649 & 0.698 & 0.052 \\
.30 & 0.357 & 0.409 & 0.464 & 0.520 & 0.575 & 0.628 & 0.679 & 0.725 & 0.768 & 0.051 \\
.40 & 0.442 & 0.497 & 0.553 & 0.607 & 0.659 & 0.707 & 0.751 & 0.790 & 0.825 & 0.048 \\
.50 & 0.531 & 0.586 & 0.638 & 0.688 & 0.734 & 0.775 & 0.812 & 0.843 & 0.871 & 0.043 \\
.60 & 0.617 & 0.669 & 0.716 & 0.759 & 0.797 & 0.831 & 0.860 & 0.885 & 0.906 & 0.036 \\
.70 & 0.697 & 0.742 & 0.783 & 0.818 & 0.849 & 0.875 & 0.898 & 0.916 & 0.932 & 0.029 \\
.80 & 0.767 & 0.804 & 0.837 & 0.865 & 0.889 & 0.909 & 0.926 & 0.940 & 0.951 & 0.023 \\
.90 & 0.824 & 0.854 & 0.880 & 0.902 & 0.920 & 0.935 & 0.947 & 0.957 & 0.965 & 0.018 \\
\hline Avg. change & 0.076 & 0.075 & 0.073 & 0.069 & 0.065 & 0.060 & 0.055 & 0.049 & 0.043 & --- \\
\hline
\end{tabular}




\section{References}

Benartzi, S., Michaely, R., and R. Thaler, 1997. Do changes in dividends signal the future or the past? Journal of Finance 52, 1007-1034.

DeAngelo, H., DeAngelo, L., and D. Skinner, 2004. Are dividends disappearing? Dividend concentration and the consolidation of earnings. Journal of Financial Economics 72, 425-456.

Easterbrook, F., 1984. Two agency-cost explanations of dividends. American Economic Review 74, 650659.

Fama, E. and K. French, 2001. Disappearing dividends: Changing firm characteristics or lower propensity to pay? Journal of Financial Economics 60, 3-43.

Fama, E. and K. French, 2004. Financing decisions: Who issues stock? Forthcoming Journal of Financial Economics.

Feldstein, M. and J. Green, 1983. Why do companies pay dividends? American Economic Review 73, pp. 17-30.

Grullon, G., Michaely, R., and B. Swaminathan, 2002. Are dividend changes a sign of firm maturity? Journal of Business 75, 387-424.

Jensen, M., 1986. Agency costs of free cash flow, corporate finance, and takeovers. American Economic Review 76, 323-329.

Jensen, M., and W. Meckling, 1976. Theory of the firm: Managerial behavior, agency costs, and ownership structure. Journal of Financial Economics 3, 305-360.

Lintner, J., 1956. Distribution of incomes of corporations among dividends, retained earnings, and taxes. American Economic Review 46, 97-113.

Myers, S. and N. Majluf, 1984. Corporate financing and investment decisions when firms have information that investors do not have. Journal of Financial Economics 12, 187-221.

Opler, T., Pinkowitz, L., Stulz, R., and R. Williamson, 1999. The determinants and implications of corporate cash holdings. Journal of Financial Economics 52, 3-46.

Stulz, R., 1990. Managerial discretion and optimal financial policies. Journal of Financial Economics 26, 3-26. 